\title{
Transcriptome profiling of granulosa cells of bovine ovarian follicles during growth from small to large antral sizes
}

Nicholas Hatzirodos ${ }^{1}$, Helen F Irving-Rodgers ${ }^{1,2}$, Katja Hummitzsch ${ }^{1}$, Margaret L Harland ${ }^{1}$, Stephanie E Morris ${ }^{1}$ and Raymond J Rodgers ${ }^{1 *}$

\begin{abstract}
Background: At later stages of folliculogenesis, the mammalian ovarian follicle contains layers of epithelial granulosa cells surrounding an antral cavity. During follicle development granulosa cells replicate, secrete hormones and support the growth of the oocyte. In cattle, the follicle needs to grow $>10 \mathrm{~mm}$ in diameter to allow an oocyte to ovulate, following which the granulosa cells cease dividing and differentiate into the specialised cells of the corpus luteum. To better understand the molecular basis of follicular growth and granulosa cell maturation, we undertook transcriptome profiling of granulosa cells from small $(<5 \mathrm{~mm} ; \mathrm{n}=10)$ and large $(>10 \mathrm{~mm}, \mathrm{n}=4)$ healthy bovine follicles using Affymetrix microarrays (24,128 probe sets).

Results: Principal component analysis for the first two components and hierarchical clustering showed clustering into two groups, small and large, with the former being more heterogeneous. Size-frequency distributions of the coefficient of variation of the signal intensities of each probe set also revealed that small follicles were more heterogeneous than the large. IPA and GO enrichment analyses revealed that processes of axonal guidance, immune signalling and cell rearrangement were most affected in large follicles. The most important networks were associated with: (A) Notch, SLIT/ROBO and PIBK signalling, and (B) ITGB5 and extracellular matrix signalling through extracellular signal related kinases (ERKS). Upstream regulator genes which were predicted to be active in large follicles included STAT and XBP1. By comparison, developmental processes such as those stimulated by KIT, IHH and MEST were most active in small follicles. MGEA5 was identified as an upstream regulator in small follicles. It encodes an enzyme that modifies the activity of many target proteins, including those involved in energy sensing, by removal of $\mathrm{N}$-acetylglucosamine from serine and threonine residues.
\end{abstract}

Conclusions: Our data suggest that as follicles enlarge more genes and/or pathways are activated than are inactivated, and gene expression becomes more uniform. These findings could be interpreted that either the cells in large follicles are more uniform in their gene expression, or that follicles are more uniform or a combination of both and that additional factors, such as LH, are additionally controlling the granulosa cells.

Keywords: Ovary, Microarray analysis, Bovine, Granulosa cells, Follicles

\footnotetext{
* Correspondence: ray.rodgers@adelaide.edu.au

${ }^{1}$ Research Centre for Reproductive Health, Discipline of Obstetrics and Gynaecology, School of Paediatrics and Reproductive Health, Robinson Institute, University of Adelaide, Adelaide, SA 5005, Australia

Full list of author information is available at the end of the article
} 


\section{Background}

An ovarian primordial follicle is composed of an inactive oocyte surrounded by granulosa cells all enclosed by a basal lamina. Once activated the follicle grows by enlargement of the oocyte and replication of the granulosa cells from about 24 cells to 50 million cells in the cow [1]. During growth, a fluid-filled antrum or cavity also develops in the middle of the follicle [2] and bovine follicles need to enlarge to over $10 \mathrm{~mm}$ in diameter, principally by antrum expansion, to be capable of ovulation. Ovulation occurs only once per oestrous cycle. However, instead of one primordial follicle growing to the necessary size and then ovulating, many follicles commence growth during the course of the cycle. The vast majority of these growing follicles become atretic leaving in cows only one, or occasionally two, follicles to ovulate. The process of follicle growth during a cycle is not random either, since two or three groups or waves of follicles emerge from a pool of follicles of approximately $5 \mathrm{~mm}$ in diameter during each oestrous cycle $[3,4]$. During these maturational waves, follicles continue to enlarge over several days until one follicle that is growing faster and is hence larger than the others gains dominance $[5,6]$. Thus a deviation in the size of follicles occurs when they are around 7-8 $\mathrm{mm}$ in diameter [7]. As the larger dominant follicle continues to expand further, the smaller follicles in the wave undergo atresia. If the wave is at the end of a cycle the dominant follicle ovulates and a new cycle is initiated. In earlier waves the dominant follicle also eventually undergoes atresia and another wave then ensues.

During growth of the follicle, the granulosa cells undergo a number of maturational changes. Early in follicle development they secrete the hormone inhibin and later at the pre-ovulatory sizes, oestradiol. The cells also express follicle-stimulating hormone receptors soon after follicle activation and then during the course of dominance they additionally express luteinising hormone receptors (LHCGR). The process of dominance is not well understood largely because it is not possible to trace the cellular changes that occur within a follicle in real time in order to relate the events preceding development to future outcomes, such as predicting whether an individual follicle will become dominant or subordinate. Another recent approach compared identical-sized follicles before deviation into dominant and subordinate follicles and analysed gene expression [8]. In that study a firm hypothesis was investigated and it was found that follicles with the highest level of CYP11A1, encoding the rate limiting enzyme for progesterone synthesis, also had the highest level of CYP19A1, encoding the ratelimiting enzyme for oestradiol synthesis [8]. It also had the highest expression level of three genes ( $L A M B 2$, COL4A1, HSPG2), encoding components of an unusual basal lamina matrix, focimatrix (abbreviated from focal intra-epithelial matrix) [8]. It was concluded that since these five genes continue to be further up regulated in dominant and preovulatory-size follicles and because the expression levels of these genes were correlated with each other, that focimatrix production and CYP11A1 expression might be important in a follicle gaining dominance [8].

Focimatrix develops as aggregates of basal lamina material deposited between the granulosa cells and contains the $\alpha 1$ and $\alpha 2$ chains of collagen type IV, laminin $\alpha 1, \beta 2$ and $\gamma 1$ chains, nidogen- 1 and -2 , perlecan, collagen type XVIII and usherin, but not versican [9]. These components are similar to those found in the follicular basal lamina at the stage of follicular development when focimatrix is first observed $[10,11]$. Focimatrix initially appears in bovine follicles greater than $5 \mathrm{~mm}$ in diameter, and the amount of focimatrix increases with increasing follicular size [9]. This first appearance of focimatrix occurs as follicles emerge in a growth wave, and prior to emergence of the dominant follicle.

The aim of this study, therefore, was to identify the important processes occurring at the key stages of antral follicle development at the time 1) prior to follicles entering a wave and 2) prior to ovulation, by gene expression array profiling. In order to gain a greater knowledge of the mechanisms responsible for granulosa cell maturation and selection of dominant follicles there have been several transcriptome analyses of bovine granulosa cells [12-17]. Evans and colleagues [12] examined dominant and subordinate follicles (some of which were atretic) by two-color hybridisation on a self -generated array containing approximately 1,300 putative genes. Serial Analysis of Gene Expression (SAGE) tags were examined in follicles of a larger size $(8 \mathrm{~mm})$ around the time of deviation for selection of the dominant follicle [13]. Skinner et al. [14] isolated healthy antral follicles at three different sizes, and used pooled follicle RNA to hybridise to individual arrays. Liu et al. [15] was also interested in selection of the dominant follicle using a two color array, but did not separate the granulosa and thecal compartments for analysis. Subordinate, dominant and preovulatory follicles have also been examined by RNA-seq and the effects of lactation examined on gene expression pathways [16]. More recently, Christenson et al. [17] also used microarray analysis to investigate gene expression in bovine antral follicles before and after the LH surge. Only in one of these studies were comparisons made between small follicles, less than $5 \mathrm{~mm}$ in diameter, and larger follicles, but the analysis may have been compromised by a lack of statistical power $(n=2$ / group). Smaller follicles represent those before focimatrix is expressed and before follicles have entered a wave. Hence we chose to compare these smaller follicles with larger preovulatory-size follicles; all of which were validated as healthy. Additionally we ensured that the isolated granulosa cells were devoid of any potentially contaminating theca cells. 


\section{Results and discussion}

\section{Selection of follicles for analyses}

To ensure accurate comparisons were made between granulosa cells from small (3.2 \pm SEM $0.2 \mathrm{~mm}$ in diameter; $\mathrm{n}=10)$ versus large $(15.3 \pm 0.6 \mathrm{~mm} ; \mathrm{n}=4)$ follicles, only antral follicles of healthy morphology $[18,19]$ were selected for this study. Confirmation of health stage was also performed on large follicles showing CYP19A1 expression assessed by qRT-PCR similar to that observed in healthy large follicles using microarray analysis (Figure 1) [20]. To ensure that the isolated granulosa cells were not contaminated with any thecal cells the level of $C Y P 17 A 1$ was measured. CYP17A1 is expressed exclusively in thecal cells [21]. No follicles with more than $1 \%$ level of expression of CYP17A1 found in thecal samples were included in the analysis. Since there were some low yields of RNA, three of the samples of small follicles were pools of two follicles, each from the same animal.

\section{Validation of microarray data}

To confirm changes in the expression of genes identified by microarray analysis, quantitative RT-PCR analyses of CYP19A1 were performed on the same samples. Similar to that observed in microarray analysis, the expression of CYP19A1 was significantly increased in granulosa cells isolated from large follicles compared to granulosa cells isolated from small follicles (Figure 1). The microarray analyses also identified genes well known to be up regulated across the sizes of follicles examined. Some examples of these include hormone-related genes CYP11A1 (increased 5.8 fold), HSD3B1 (6.0 fold), LHCGR (8.8 fold) and INHBA (3.8 fold) and focimatrix genes COL4A1 (6.8 fold) and LAMA1 (5.8 fold) as shown previously $[20,22]$ (Table 1$)$.

\section{Statistical analyses of gene expression}

Granulosa from small healthy follicles were from one of two groups having either columnar $(n=5)$ or rounded $(\mathrm{n}=5)$ shaped basally-situated granulosa cells as described in the Methods. Principal component analysis (PCA) for the first three components (Figure 2) and hierarchical clustering (Additional file 1: Figure S1) for the total number of probe sets $(n=24,182)$ of all arrays in this study was conducted. Neither of these unsupervised analytical methods separated the small healthy follicle arrays into the rounded and columnar groups, and in fact no genes were shown to be more than 2-fold differentially expressed between the two subgroups with a Benjamini-Hochberg False Discovery Rate (FDR) of $P<0.05$ by ANOVA. Therefore, the small healthy follicles were treated as a single group for further analyses $(n=10)$ and compared with the group of large follicles $(n=4)$. It can be clearly seen that the large follicles clustered comparatively closely together and differed from the small healthy follicles, which appeared to be more variable across the group. This was also reflected in the hierarchical clustering analysis (Additional file 1: Figure S1). Seven hundred and fifty eight probe sets were found to be differentially expressed between small and large follicles, when a $P<0.05$ and an arbitrary threshold of 3-fold minimum differential expression was applied (Table 2). These consisted of 579 up-regulated and 179 down-regulated probe sets in large with respect to small follicles. The fact that substantially more genes were up regulated than down regulated in large healthy follicles, could indicate that activation rather than a reduction in additional pathways occurs as follicles enlarge.

\section{Variability of gene expression}

The Coefficient of Variation (SD/Mean X $100=\mathrm{CV}$ ) for each gene in small and in large follicles in both the complete probe set and the $>2$-fold differentially regulated probe set were calculated. The CV-frequency distribution plots are shown in Figure 3. The small follicles (Figure 3A) had more genes that were variably expressed, particularly for the genes whose expression was $>2$-fold differentially regulated between small and large follicles (Figure 3B). Furthermore, when we repeated the analysis using only the genes whose signal intensities were in the top $50 \%$ on
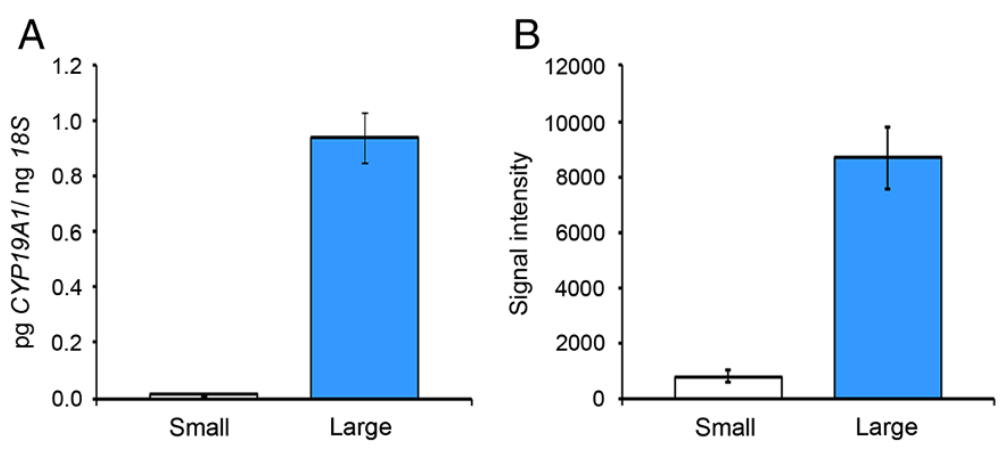

Figure 1 Quantitative RT-PCR analysis of CYP19 expression (A) compared with gene induction profiles observed by microarray analysis (B). Mean \pm SEM expression of CYP19 was determined in granulosa cells derived from the 10 small (clear columns) and 4 large follicles (blue columns) used for the microarray analysis. Microarray signal data were non-log transformed and divided by $10^{4}$. 
Table 1 Genes which are up regulated in large follicles with respect to small folliclest

\begin{tabular}{|c|c|c|c|c|c|}
\hline Gene symbol & Fold change & Gene symbol & Fold change & Gene symbol & Fold change \\
\hline \multicolumn{6}{|c|}{ Cell cycle } \\
\hline RASA2 & 5.5 & TACC1 & 3.5 & RAD50 & 3.1 \\
\hline TBCEL & 4.8 & TOPORS & 3.3 & HELZ & 3.1 \\
\hline CDK13 & 4.3 & TRIB2 & 3.2 & & \\
\hline TPR & 4.3 & ANAPC5 & 3.1 & & \\
\hline \multicolumn{6}{|c|}{ Cell morphology } \\
\hline LIMA1 & 8.2 & FERMT2 & 4.2 & $A R P C 1 B$ & 3.3 \\
\hline SLMAP & 5.1 & TTLL3 & 3.9 & & \\
\hline MYO1B & 5.1 & ABLIM1 & 3.7 & & \\
\hline \multicolumn{6}{|c|}{ Cytokines, hormones and receptors } \\
\hline IFI30 & 39.0 & F2RL1 & 5.3 & THBS3 & 3.5 \\
\hline PTHLH & 12.8 & DKK3 & 5.3 & IGFBP6 & 3.5 \\
\hline$F 2 R$ & 8.9 & NPR3 & 5.2 & $B M P R 2$ & 3.3 \\
\hline LHCGR & 8.8 & LPHN2 & 4.7 & BAI2 & 3.3 \\
\hline IGFBP4 & 7.3 & $P G R$ & 4.7 & GPR88 & 3.2 \\
\hline$F 3$ & 7.2 & TNFAIP8L3 & 4.7 & SCG2 & 3.2 \\
\hline OPTN & 6.5 & GABARAPL1 & 4.6 & OSBPL8 & 3.1 \\
\hline IL4R & 6.2 & STRA6 & 4.2 & TM2D1 & 3.1 \\
\hline IL6R & 5.7 & RYK & 4.2 & BMPR1A & 3.1 \\
\hline GRK5 & 5.6 & INHBA & 3.8 & NRP1 & 3.0 \\
\hline NR5A2 & 5.5 & LGALS3BP & 3.5 & GPR173 & 3.0 \\
\hline PTGFR & 5.5 & & & & \\
\hline \multicolumn{6}{|c|}{ Directional cell growth } \\
\hline LRP8 & 53.6 & SLITRK2 & 5.1 & SEMA6A & 3.3 \\
\hline EFNA5 & 8.6 & PLXNC1 & 4.8 & NINJ1 & 3.2 \\
\hline MPP5 & 7.1 & PLXNB2 & 4.7 & $R O B O 1$ & 3.1 \\
\hline $\mathrm{ROBO2}$ & 6.7 & ${ }^{*} E P H B 6$ & 3.8 & ROCK1 & 3.1 \\
\hline SEMA6D & 6.2 & COLEC11 & 3.5 & & \\
\hline \multicolumn{6}{|c|}{ Extracellular matrix and synthesis } \\
\hline TNFAIP6 & 279.6 & COL16A1 & 6.0 & VCAN & 5.0 \\
\hline SPOCK2 & 22.0 & LAMA1 & 5.8 & LEPREL 1 & 4.9 \\
\hline COL4A1 & 6.8 & PCOLCE & 5.7 & SDC2 & 3.8 \\
\hline \multicolumn{6}{|c|}{ Intercellular and cell to matrix adhesion } \\
\hline ARHGAP18 & 20.5 & $\mathrm{CDH} 11$ & 4.6 & TSPAN9 & 3.4 \\
\hline ITGB5 & 11.4 & ${ }^{*} B S T 2$ & 4.4 & PARD3B & 3.2 \\
\hline VCAM1 & 7.3 & TNS3 & 3.6 & TSPAN2 & 3.0 \\
\hline CSPG4 & 5.5 & CCM2 & 3.6 & UBQLN1 & 3.0 \\
\hline ARHGAP17 & 4.8 & & & & \\
\hline \multicolumn{6}{|c|}{ Ion transport } \\
\hline *TMEM20 & 4.3 & & & & \\
\hline \multicolumn{6}{|c|}{ Protein trafficking } \\
\hline HSP9OAA1 & 7.0 & SH3GL2 & 4.1 & $R A B 7 A$ & 3.3 \\
\hline TMEM27 & 5.1 & SCYL2 & 4.0 & $C L G N$ & 3.2 \\
\hline GOLGA4 & 4.6 & MLEC & 3.8 & CLTC & 3.2 \\
\hline
\end{tabular}


Table 1 Genes which are up regulated in large follicles with respect to small folliclest (Continued)

\begin{tabular}{|c|c|c|c|c|c|}
\hline TMEM47 & 4.5 & PLEKHG1 & 3.6 & FKBP9 & 3.1 \\
\hline PLEKHA2 & 4.2 & PLEKHB2 & 3.5 & CANX & 3.1 \\
\hline PLEKHH3 & 4.1 & GD/1 & 3.4 & & \\
\hline \multicolumn{6}{|c|}{ Proteolysis or inhibition } \\
\hline PRSS23 & 48.5 & ADAMTS4 & 4.7 & FBXL20 & 3.9 \\
\hline PLAT & 17.5 & HM13 & 4.5 & ADAM10 & 3.7 \\
\hline ACE2 & 12.9 & RNF128 & 4.5 & MYCBP2 & 3.4 \\
\hline$C P D$ & 11.8 & CTSB & 4.4 & HERPUD1 & 3.3 \\
\hline SERPINA5 & 11.2 & SPG7 & 4.2 & RNF20 & 3.3 \\
\hline ECE1 & 9.5 & DERL1 & 4.1 & UBR3 & 3.2 \\
\hline ADAM9 & 8.4 & USP4 & 4.0 & MARCH5 & 3.2 \\
\hline TIMP2 & 7.9 & UBR1 & 4.0 & FAF2 & 3.2 \\
\hline ADAM12 & 6.6 & MARCH6 & 3.9 & TTC3 & 3.1 \\
\hline USP7 & 6.4 & & & & \\
\hline \multicolumn{6}{|c|}{ RNA processing } \\
\hline NOL3 & 6.0 & PBRM1 & 4.3 & $L U C 7 L 3$ & 3.8 \\
\hline CPEB4 & 5.1 & PRPF38B & 4.2 & PNISR & 3.7 \\
\hline UTP6 & 4.8 & RBM5 & 4.0 & SYNCRIP & 3.6 \\
\hline CSDE1 & 4.7 & TIA1 & 3.9 & RNASEK & 3.6 \\
\hline CHD1 & 4.7 & CTR9 & 3.9 & $D D \times 46$ & 3.4 \\
\hline SF3B1 & 4.6 & HNRPLL & 3.9 & DICER1 & 3.1 \\
\hline RBM 25 & 4.4 & & & & \\
\hline \multicolumn{6}{|c|}{ Transcription regulation } \\
\hline TOX & 11.4 & ZNF317 & 3.8 & BRWD1 & 3.3 \\
\hline NMI & 8.4 & HUWE1 & 3.8 & NOSTRIN & 3.2 \\
\hline NOTCH1 & 8.4 & TRIM25 & 3.7 & JARID2 & 3.2 \\
\hline TOB1 & 6.3 & CREB3L2 & 3.7 & ZNF462 & 3.1 \\
\hline ZNF292 & 6.0 & $A D N P$ & 3.7 & ANKRD10 & 3.1 \\
\hline MTPN & 5.7 & ZNF609 & 3.6 & CITED2 & 3.1 \\
\hline AFF1 & 5.5 & KLF6 & 3.5 & MED24 & 3.1 \\
\hline FOXP2 & 5.3 & ${ }^{*} M L L 3$ & 3.5 & GPS2 & 3.1 \\
\hline ID2 & 4.5 & NCOR1 & 3.5 & HMGXB3 & 3.1 \\
\hline ID3 & 4.3 & RBFOX2 & 3.4 & TFCP2 & 3.1 \\
\hline *SON & 4.2 & ZNF24 & 3.3 & CITED1 & 3.1 \\
\hline WHSC1L1 & 3.9 & & & & \\
\hline \multicolumn{6}{|c|}{ Translation regulation } \\
\hline EIF4G3 & 7.4 & BZW2 & 3.6 & EIF2C2 & 3.3 \\
\hline EIF4EBP1 & 7.3 & EIF2C3 & 3.4 & & \\
\hline BZW1 & 4.2 & IREB2 & 3.4 & & \\
\hline \multicolumn{6}{|c|}{ Transport } \\
\hline SLC5A11 & 15.6 & MAL2 & 3.8 & SEC63 & 3.4 \\
\hline$A P O A 2$ & 12.5 & CLIC4 & 3.7 & STAR & 3.4 \\
\hline SLC39A8 & 9.1 & CPNE8 & 3.7 & TFR2 & 3.3 \\
\hline$A P 2 B 1$ & 6.8 & ATP13A3 & 3.6 & COPZ1 & 3.3 \\
\hline$S L C 25 A 28$ & 5.8 & SLC25A12 & 3.6 & MICU1 & 3.2 \\
\hline
\end{tabular}


Table 1 Genes which are up regulated in large follicles with respect to small folliclest (Continued)

\begin{tabular}{|c|c|c|c|c|c|}
\hline SLC27A3 & 5.7 & SLC26A11 & 3.6 & NUP85 & 3.2 \\
\hline TNPO1 & 5.5 & AP3S2 & 3.6 & CYCS & 3.2 \\
\hline SLC4OA1 & 5.3 & TM9SF4 & 3.5 & $A P O A 1$ & 3.2 \\
\hline$A B C B 1$ & 5.1 & AP1S2 & 3.5 & CLTC & 3.2 \\
\hline ATP6V1A & 4.3 & ACBD5 & 3.5 & STBD1 & 3.1 \\
\hline RRBP1 & 4.2 & & & & \\
\hline \multicolumn{6}{|c|}{ Other enzymes } \\
\hline ME3 & 26.7 & PTPN13 & 4.2 & GPX3 & 3.2 \\
\hline$C Y B B$ & 18.1 & SCD5 & 4.2 & PDP1 & 3.2 \\
\hline CYP19A1 & 14.2 & FDFT1 & 4.1 & LARGE & 3.2 \\
\hline NT5E & 12.8 & UGCG & 4.0 & MLL5 & 3.2 \\
\hline$R G N$ & 9.8 & DPYSL2 & 3.8 & EDEM2 & 3.1 \\
\hline PYGL & 8.9 & PLD1 & 3.7 & NCEHI & 3.1 \\
\hline B3GALT2 & 6.5 & PPAP2B & 3.7 & XRN2 & 3.1 \\
\hline PDSS1 & 6.0 & TET2 & 3.7 & RDH11 & 3.1 \\
\hline HSD3B2 & 6.0 & PFKM & 3.7 & CHST10 & 3.1 \\
\hline PPM1K & 5.9 & SGSH & 3.6 & PTP4A2 & 3.1 \\
\hline CYP11A1 & 5.8 & CUL3 & 3.5 & PTPN11 & 3.1 \\
\hline PIGS & 5.5 & QSOX1 & 3.5 & $M A O A$ & 3.1 \\
\hline IDH3A & 5.5 & ACSS2 & 3.5 & CA8 & 3.0 \\
\hline CMAHP & 4.6 & $D P Y D$ & 3.4 & HECTD1 & 3.0 \\
\hline PDPK1 & 4.5 & MTR & 3.4 & PPP2R5E & 3.0 \\
\hline AHCYL2 & 4.4 & POR & 3.3 & CUL1 & 3.0 \\
\hline \multicolumn{6}{|c|}{ Other signalling } \\
\hline BEX2 & 9.0 & ARHGEF3 & 4.8 & *PRKAG2 & 3.4 \\
\hline PIK3R1 & 9.0 & AMIGO2 & 4.7 & SNTB2 & 3.4 \\
\hline DTNA & 8.5 & MAP2K4 & 4.4 & GLG1 & 3.3 \\
\hline DACT1 & 8.4 & NDRG3 & 4.4 & GNA11 & 3.3 \\
\hline ARFGAP3 & 7.6 & $A P C$ & 4.0 & IER3 & 3.3 \\
\hline GADD45B & 6.8 & PDCD4 & 4.0 & $\mathrm{NISCH}$ & 3.3 \\
\hline NDRG4 & 6.7 & $B M P 2 K$ & 3.8 & INSIG2 & 3.2 \\
\hline BCAS3 & 6.0 & $|f i 27| 1$ & 3.7 & STIM1 & 3.2 \\
\hline MIA3 & 5.4 & ERRFI1 & 3.6 & $B C L 2 L 2$ & 3.2 \\
\hline MS4A8B & 5.3 & ARHGEF6 & 3.5 & PIP4K2A & 3.1 \\
\hline SAFB2 & 4.9 & FICD & 3.4 & KIRREL & 3.0 \\
\hline MAPK6 & 4.8 & & & & \\
\hline \multicolumn{6}{|c|}{ Other } \\
\hline FAM114A1 & 18.8 & TMEM176A & 4.1 & ANKRD12 & 3.4 \\
\hline$D D \times 26 B$ & 9.7 & WDFY4 & 3.9 & ${ }^{*} W D F Y 2$ & 3.4 \\
\hline LHFPL2 & 6.8 & PSMD4 & 3.8 & $\mathrm{CHCHD10}$ & 3.3 \\
\hline RNF213 & 5.9 & RHBDD2 & 3.8 & MRAP & 3.3 \\
\hline OBSL1 & 5.8 & ${ }^{*}$ ZNF317 & 3.8 & TMEM5OB & 3.2 \\
\hline USHBPI & 5.2 & TMEM176B & 3.7 & BRWD3 & 3.2 \\
\hline RSRC2 & 5.1 & PSAP & 3.7 & ${ }^{*}$ OXR1 & 3.2 \\
\hline KLHL28 & 5.0 & LRIG3 & 3.7 & HIATL1 1 & 3.1 \\
\hline
\end{tabular}


Table 1 Genes which are up regulated in large follicles with respect to small folliclest (Continued)

\begin{tabular}{|c|c|c|c|c|c|}
\hline LINGO2 & 5.0 & AKAP8L & 3.6 & MGARP & 3.1 \\
\hline PDLIM4 & 5.0 & FAM126B & 3.6 & PHF3 & 3.1 \\
\hline ODF2L & 4.4 & RCN3 & 3.6 & MPV17L2 & 3.1 \\
\hline BTBD7 & 4.3 & $L R R C 2$ & 3.6 & TBC1D5 & 3.0 \\
\hline RNF144B & 4.3 & SUSD4 & 3.5 & Gm16462/ & 3.0 \\
\hline R3HCCl & 4.2 & UHRF1BP1L & 3.5 & Gm8787 & \\
\hline TXNIP & 4.1 & YPEL5 & 3.5 & VWA1 & 3.0 \\
\hline RCAN3 & 4.1 & FAM174B & 3.4 & ZBTB33 & 3.0 \\
\hline
\end{tabular}

${ }^{\dagger}(\geq 3$ fold, $P<0.05)$ and categorised by function. Genes are listed in descending order of fold change within each category. Significance was determined by Benjamini-Hochberg post-hoc test for multiple corrections following one way ANOVA.

*indicates genes determined from the Partek analysis based on the Affymetrix annotations which were not assigned identities by IPA.

the array we still observed a shift to increased variation, thus demonstrating that this property is inherent in the small follicles rather than possibly due to overall lower array intensities (Additional file 2: Figure S2). The higher variability in gene expression in the small follicle granulosa cells indicates that either the cells in small follicles were less uniform in their gene expression, or that small follicles were less uniform or a combination of both. The more variably expressed genes were up regulated during follicle enlargement which indicates that the reduction in variability of

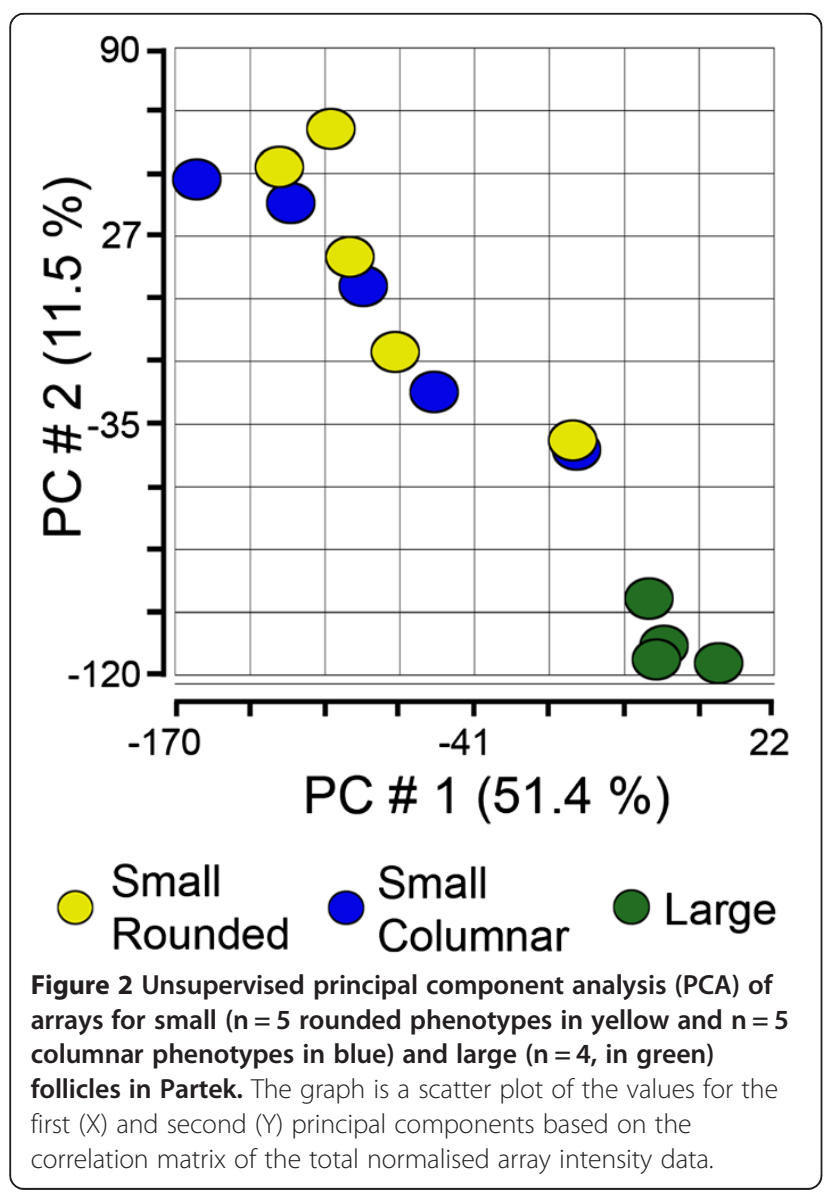

gene expression and their up regulation are potentially both important processes in follicle maturation.

\section{Differentially expressed genes}

A list of genes which were differentially regulated between small and large healthy follicles (758 probe sets, 3 -fold differentially expressed, $P<0.05$, gene list and names are shown in Additional file 3: Table S1) was examined in detail. We were able to identify genes which were well characterised during follicle development, and known to be differentially regulated between small and large follicles in our microarray analyses which included LHCGR [23], progesterone receptor [24], INHBA [25] and the receptor for the lipid mediator prostaglandin F2 $\alpha$ (PTGFR) [26]. In the list 533 probe sets could be assigned gene identities in Ingenuity Pathway Analysis (IPA) which included those with homology to multiple probe sets, consisting of 446 annotated genes, of these 352 were up regulated in large follicles (Table 1) and 92 were down regulated (Table 3). This list was also uploaded to the Gene Ontology Enrichment Analysis Software Toolkit (GOEAST) program.

\section{Pathway and network analyses}

The top ten canonical pathways generated in IPA and significant GO terms indicate a trend toward directional cell growth and extracellular signalling. In particular, the three most significantly associated IPA canonical pathways are axonal guidance (Additional file 4: Figure S3), Ephrin A and Rho GTPase signalling, which are associated with cell attachment and cytoskeletal rearrangement (Figure 4A). The

Table 2 Numbers of probe sets $\mathbf{2}$ fold or more differentially expressed in large healthy follicles with respect to small healthy follicles*

\begin{tabular}{lccc}
\hline Fold change & Up-regulated & Down-regulated & Total \\
\hline$>2$ & 1666 & 1048 & 2714 \\
$>3$ & 579 & 179 & 758 \\
$>4$ & 278 & 67 & 345
\end{tabular}

*Significant by FDR with $P<0.05$, with ANOVA in Partek using the step-up Benjamini-Hochberg FDR method for multiple corrections. 


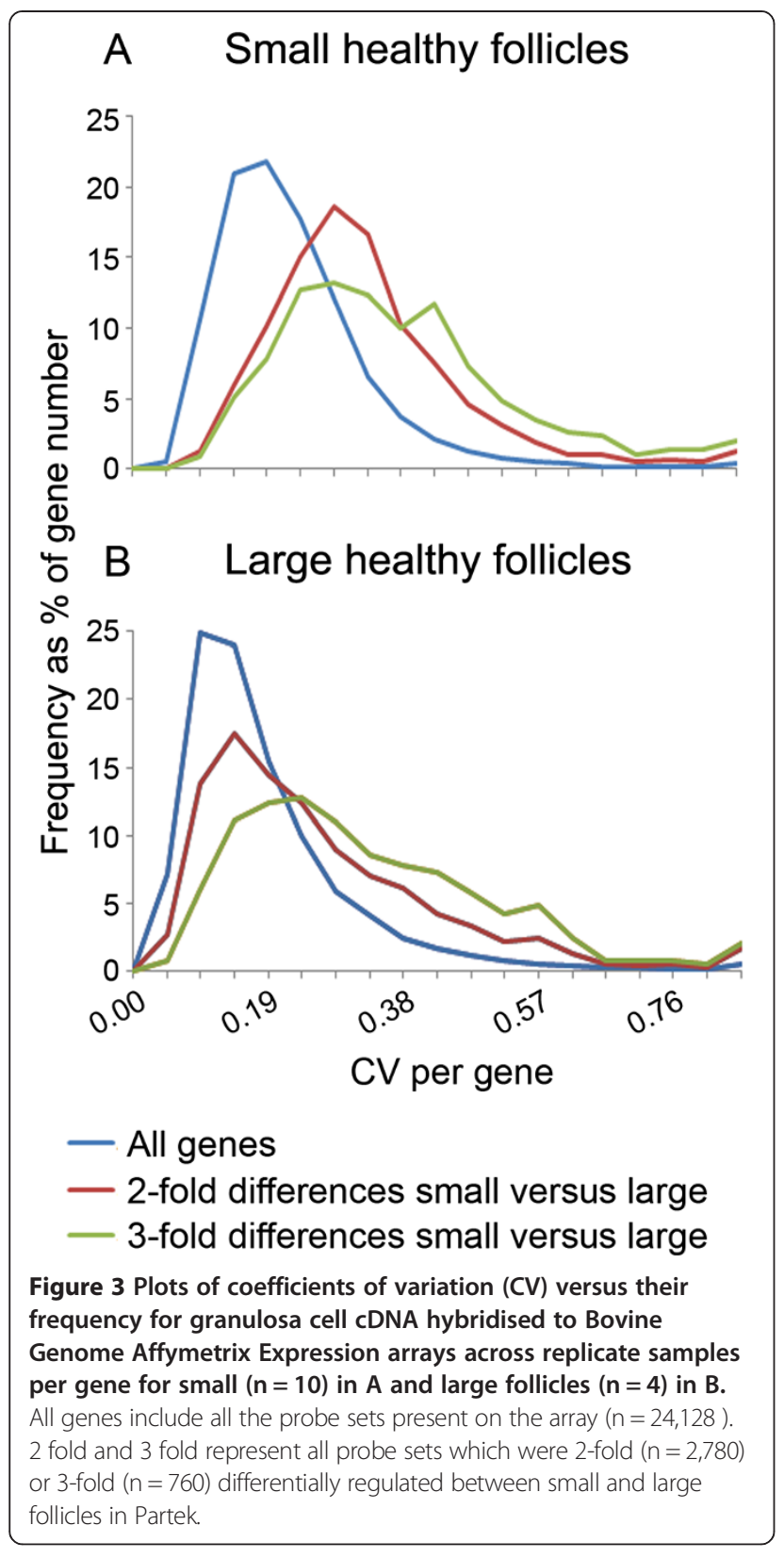

IL-6 signalling pathway (Additional file 5: Figure S4), associated with inflammation and acute phase reaction, also contains a number of genes which were activated in large follicles including IL6R, JNK, PIK3R and TSG6 (or TNFAIP6, already mentioned). The GO terms enriched for the large to small follicle comparison are also connected with inflammation signalling and cell rearrangement (Figure 4B).

The two top networks generated by IPA based on the dataset above are shown in Figure 5. The network in Figure 5A shows an emphasis on cytoplasmic membrane receptor signalling centred around Notch and the ADAM protease genes and axonal guidance through the ROBO genes and LRP8. There is also considerable connectivity associated with $P I 3 K$ which exerts direct effects on the cytoskeleton and indirectly protein translation via EI4EBP1. The other network (Figure 5B) indicates significant interaction with extracellular matrix by $L A M A 1$, $L A M C 2$ and COL4A1 which appear to mainly signal through the cell surface components ITGB5, CSPG4 and CDH11 to ERK pathways. This extracellular matrix pathway is probably that associated with focimatrix production that develops as follicles enlarge from 5 to $10 \mathrm{~mm}$ in diameter $[9,27]$.

\section{Genes activated in large versus small follicles TGF- $\beta$ signalling}

It is well known that TGF- $\beta$ signalling plays an important role in follicular development, as reviewed by Knight and Glister in 2006 [28] and more recently by Myers and Pangas in 2010 [29]. In our study, three members of the TGF- $\beta$ superfamily, INHBA which helps drive androgen production from the theca [30] and inhibits production of FSH by the pituitary [31], and the bone morphogenetic protein receptor genes $B M P R 1 A$ and $B M P R 2$, were up regulated in large follicles (Table 1 ). The BMP receptor type II binds GDF-9 and BMP-15, two critical growth factors for granulosa cells which are secreted by the oocyte at antral stages [32]. The activation of these genes probably contributes to follicle growth during the latter antral stages when androgen production is increased and combines with LH to maintain high oestradiol levels following the reduction in circulating levels of FSH when a dominant follicle emerges.

\section{Immune/Inflammation signalling}

The immunoregulatory receptor genes, IL4R IL6R and $I L 20 R A$ and the thrombin and thrombin-like receptors $F 2 R$ and F2RL1were also identified among the list of genes activated in large follicles (Table 1). Bovine granulosa cells have been shown to be capable of initiating an inflammatory response to lipopolysaccharide with increased expression of IL- 6 and IL-8 [33]. Additionally, IL-6 and its receptor have been studied in relation to cumulus-oocyte complex development, where they are known to play an active role in expansion and ovulation [34]. The expression of another inflammatory cytokine IL-4 and its receptor have been shown to increase in the rat preovulatory follicle [35]. Interestingly, thrombin receptor RNA expression has previously been reported to be lower in larger follicles than small [36] as opposed to our study, though the health of the follicles was unclear in the other study. These inflammatory pathways identified as significant in our analysis further confirm that significant signalling through these pathways occurs in the later stages of bovine antral follicle development. 
Table 3 Genes which are down regulated in large follicles with respect to small folliclest

\begin{tabular}{|c|c|c|c|c|c|}
\hline Gene symbol & Fold change & Gene symbol & Fold change & Gene symbol & Fold change \\
\hline \multicolumn{6}{|c|}{ Cell cycle } \\
\hline RPRM & 5.8 & & & & \\
\hline \multicolumn{6}{|c|}{ Cell morphology } \\
\hline JAKMIP1 & 20.8 & MYO10 & 6.8 & ACTA1 & 3.4 \\
\hline SEPT4 & 15.3 & MFAP2 & 4.6 & MYOID & 3.0 \\
\hline \multicolumn{6}{|c|}{ Cytokines, hormones and receptors } \\
\hline KIT & 23.1 & 1433 & 3.6 & GPR77 & 3.2 \\
\hline ANGPT2 & 11.5 & PTPRN2 & 3.6 & ANGPTL2 & 3.1 \\
\hline RYR2 & 7.0 & SHISA2 & 3.5 & $F 2 R L 2$ & 3.1 \\
\hline PDGFC & 4.6 & CMTM8 & 3.4 & SFRP4 & 3.0 \\
\hline FGFR2 & 3.7 & IL2ORA & 3.4 & & \\
\hline \multicolumn{6}{|c|}{ Directional cell growth } \\
\hline FEZ1 & 3.8 & EPHA1 & 3.2 & & \\
\hline \multicolumn{6}{|c|}{ Extracellular matrix and synthesis } \\
\hline$\angle A M C 2$ & 3.4 & COLIA1 & 3.0 & & \\
\hline \multicolumn{6}{|c|}{ Intercellular and cell to matrix adhesion } \\
\hline NEDD9 & 5.9 & $\mathrm{CDH} 2$ & 4.0 & NPNT & 3.2 \\
\hline \multicolumn{6}{|c|}{ Protein trafficking } \\
\hline SNX31 & 6.0 & ADCK3 & 3.4 & $M Z B 1$ & 3.1 \\
\hline CLU & 4.9 & & & & \\
\hline \multicolumn{6}{|c|}{ Proteolysis and inhibition } \\
\hline *PTI & 5.6 & LTF & 4.0 & EPHX1 & 3.4 \\
\hline MMP16 & 4.0 & PRSS35 & 3.7 & TRIM2 & 3.3 \\
\hline \multicolumn{6}{|c|}{ RNA processing } \\
\hline CPEB1 & 3.9 & & & & \\
\hline \multicolumn{6}{|c|}{ Transcription regulation } \\
\hline MYC & 16.4 & FOS & 4.0 & $E M X 2$ & 3.1 \\
\hline HOPX & 13.8 & FHL2 & 3.3 & MSX1 & 3.1 \\
\hline TGIF1 & 6.1 & HES1 & 3.2 & & \\
\hline \multicolumn{6}{|c|}{ Transport } \\
\hline SVOPL & 8.6 & NUP210 & 4.7 & $A Q P 1$ & 3.2 \\
\hline NALCN & 6.0 & $A B C C 8$ & 4.7 & FXYD6 & 3.2 \\
\hline$A P 3 B 2$ & 5.5 & STARD10 & 3.4 & ZP3 & 3.2 \\
\hline \multicolumn{6}{|c|}{ Other enzymes } \\
\hline GATM & 11.1 & MANIA1 & 4.2 & PTGS2 & 3.5 \\
\hline CA14 & 8.8 & ENPP1 & 4.1 & ABAT & 3.5 \\
\hline PAPSS2 & 7.8 & HMOX1 & 4.1 & PFKFB3 & 3.2 \\
\hline RASL11B & 6.8 & PHGDH & 3.7 & CYP2C19 & 3.1 \\
\hline GALNT13 & 5.3 & RENBP & 3.6 & AKR1C3 & 3.1 \\
\hline AKR1B1 & 4.5 & $D D O$ & 3.6 & GYLTL1B & 3.0 \\
\hline \multicolumn{6}{|c|}{ Other signalling } \\
\hline MEST & 28.7 & GUCA1A & 5.1 & ${ }^{*} R G S 2$ & 3.4 \\
\hline TNFAIP2 & 17.5 & $H L A-A$ & 4.4 & $A P B B 2$ & 3.2 \\
\hline $\mathrm{IHH}$ & 16.6 & ${ }^{*} \mathrm{CHRDL} 1$ & 3.7 & BANK1 & 3.1 \\
\hline CARTPT & 14.0 & SASH1 & 3.5 & ${ }^{*} T C R A$ & 3.0 \\
\hline
\end{tabular}


Table 3 Genes which are down regulated in large follicles with respect to small folliclest (Continued)

\begin{tabular}{lllll}
\hline & \multicolumn{3}{c}{ Other } \\
\hline LRRC17 & 7.1 & TTN & 3.6 & MMD \\
STAC3 & 3.9 & SEL1L3 & 3.6 & 3.1 \\
LRRC1 & 3.8 & CCDC3 & 3.2 & BTNL1 \\
\hline
\end{tabular}

${ }^{\dagger}(\geq 3$-fold, $P<0.05)$ and categorised by function. Genes are listed in descending order of fold change in each category. Significance was determined by Benjamini-Hochberg post-hoc test for multiple corrections following one way ANOVA.

*indicates genes determined from the Partek analysis based on the Affymetrix annotations which were not assigned identities by IPA.

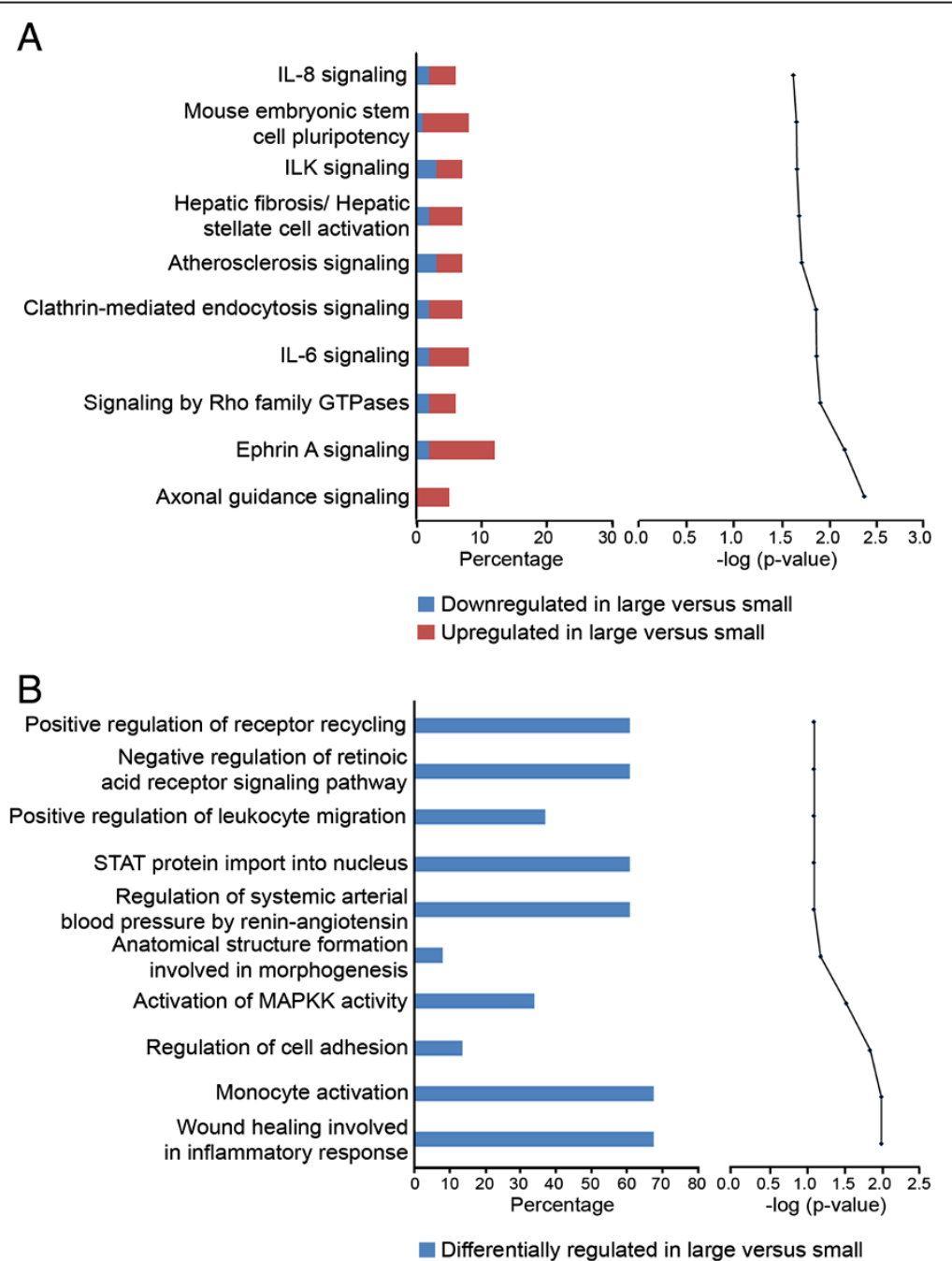

Figure 4 Top ranked canonical pathways generated in Ingenuity Pathway Analysis (A), and enriched GO terms of interest (B), determined by the GOEAST program, for a set of genes 3-fold differentially regulated with a Benjamini Hochberg False Discovery Rate $P<0.05$ between small and large follicles. A The bar chart on the left represents the percentage of genes from the data set that map to each canonical pathway showing those which are up regulated (in red) and down regulated (in blue) in large with respect to small follicles. The pathways are ranked from lowest (top) to highest (bottom) degree of association with genes from the data set by the $P$-value of a right tailed Fishers exact $t$-test. The Benjamini-Hochberg test for multiple comparisons determined that these pathways all had $-\log P$ value $=0.23$. B The bar chart on the left represents the percentage of genes differentially regulated from the data set, which map to an enriched GO term of interest classified as a biological process. The most significant terms from the analysis were not displayed as these were too general and not informative in terms of specific function. The GO terms were ranked from lowest to highest degree of association with genes from our data set, by the $P$-value calculated using the Benjamini-Yuketeli test for multiple comparisons (top to bottom in graph on right). 


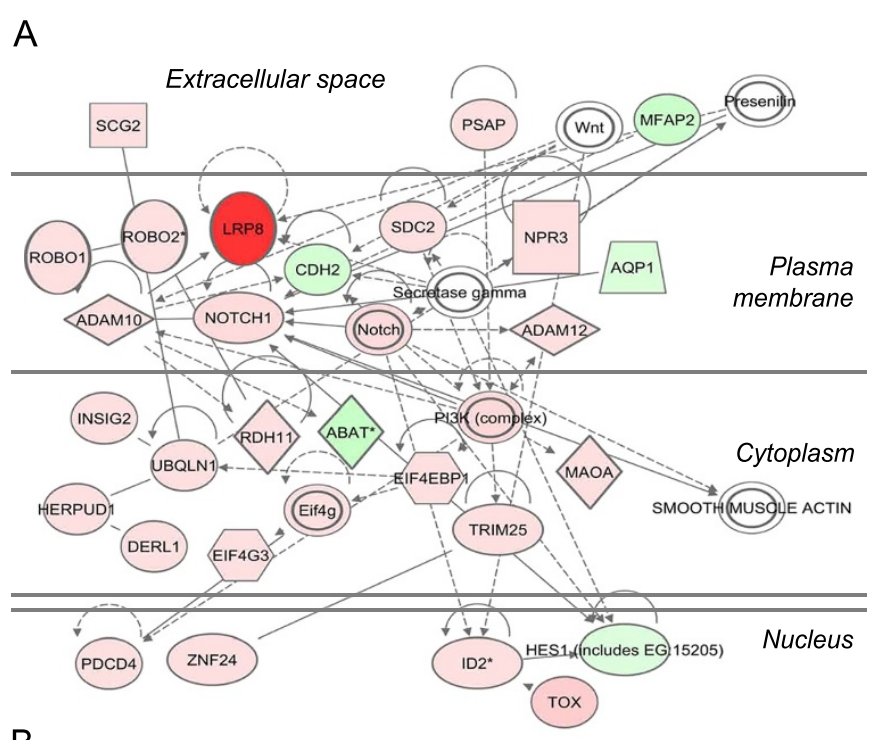

B
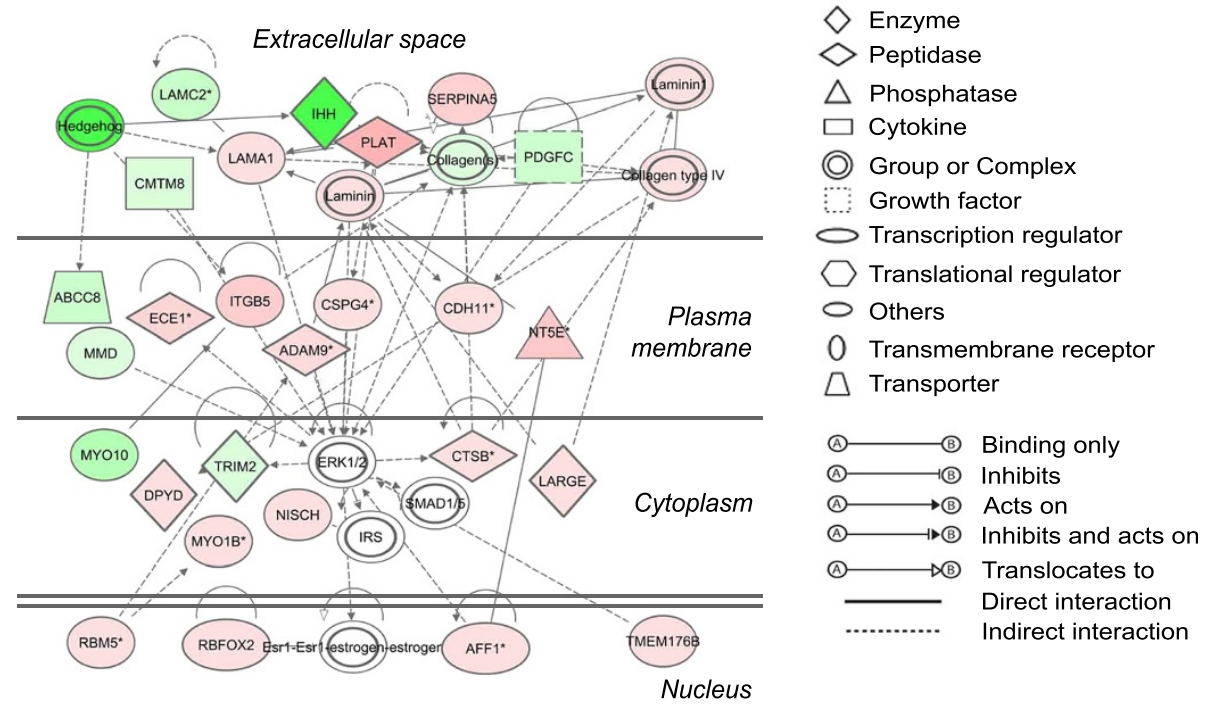

Figure 5 The two top-ranked networks (A, B) determined for molecules mapped to the IPA database from a data set containing genes differentially regulated between small and large follicles. Interactions between molecules are shown as explained in the legend, with focus molecule symbols highlighted in color, based on up (red) or down (green) regulation in large follicles and of increasing intensity with degree of fold change.

\section{Axonal guidance}

An interesting subset of the signalling genes active in large follicles is concerned with directional cell growth and cellular processes, mainly through the SLIT (SLITRK1)/ roundabout or ROBO $(R O B O 1, R O B O 2)$ and semaphorin (SEMA6A)/plexin (PLXNB2, PLEXNC1) pathways (Table 2 and Figure 5A). ROBO1 and ROBO2, and SLITRK2 are part of the SLIT-ROBO pathway, which acts as an important repulsive cellular guidance mechanism to control vascular and mesenchymal tissue development [37]. Whilst follicles do not have a branching structure, during their growth they are expanding within a stromal tissue, as branching ducts are required to do, suggesting that the semaphorin $(S E M A 6 A) /$ plexin
(PLXNB2, PLEXNC1) pathway is important in the process of follicle expansion. Another up-regulated gene NOTCH1, can similarly affect cell polarity and tissue structure [38].

In fact, these molecules are known to be present in follicle development in the fetal ovary [39] and adult ovarian follicle $[40,41]$. LRP8, an endocytosis and cholesterol transport participant, was previously found to be more highly expressed in large versus small antral follicles [42] and in the dominant follicle compared with the subordinate and preovulatory follicles [43]. LRP8 is also crucial for binding ephrins, which are involved with directed growth and cell migration [44]. Ephrin receptors, including A4 and their corresponding ligands, have been demonstrated 
in human luteinised granulosa cells [45]; but not at earlier stages. The activation of these genes and subsequent axonal guidance pathways identified in our arrays indicate the importance of polarity switching and cell rearrangement as the follicle prepares for ovulation and luteinisation of granulosa cells. Ovulation requires that the follicle and cumulus expand and the oocyte migrate to the point of release facing the ovarian surface, which necessitates coordinated signalling between mural and cumulus granulosa and the oocyte.

\section{Protein trafficking}

Molecules involved in protein trafficking constitute another important group within our up-regulated data set (Table 1), and some of these participate in cell signalling pathways through the pleckstrin homology domain binding proteins PLEKHA2, PLEKHB2, PLEKHG1 and PLEKHH3. PLEKHA2 is a participant in the phosphoinositidyl-3-phosphate kinase (PI3K) signalling pathway which is sensitive to superoxide production [46], possibly as a by-product of steroidogenesis.

\section{Transcription factors}

As the follicle enlarges the granulosa cells mature and we would expect major changes in the types of molecular pathways which are active in the granulosa cells. This is reflected in the high number of transcriptional regulators of developmental processes encoded by genes like FOXP2, CREB3L2, JARID2, CITED1 and CITED2 which are switched on in large follicles (Table 1). The cAMPresponsive element binding protein $(\mathrm{CBP})$ p300 interacting transcriptional modulator CITED1, has been shown to be activated by FSH treatment of in vitro matured granulosa cells [47], and CITED2 encodes a factor which competes with hypoxic inducible factor (HIF1 $\alpha$ ) for CBPp300 [48], and is important for embryonic development of neural tissue [49].

\section{Cell growth}

Many of the genes identified in this study encode proteins responsible for growth and metabolism. Several of these are known to be involved in follicular development and confirm previous studies, such as IGFBP-4 and-6, which were found to be up regulated in granulosa cells isolated from large follicles [50] (Table 1). Other genes such as chordinlike 1, a BMP-4 antagonist [51], have not previously been associated with follicular development.

\section{Intercellular and matrix adhesion}

A number of molecules which create intercellular interactions and/or bind extracellular matrix are also encoded by genes which are listed in Table 1 . Nine extracellular matrix genes were up regulated in large follicles, and encode proteins including collagen types $4 \alpha 1(C O L 4 A 1)$ and $16 \alpha 1$
(COL16A1), and laminin $\alpha 1$ (LAMA1), as well as the proteoglycans, versican (VCAN), CSPG4 and syndecan 2 (SCD2) (Figure 5A). This group also contains the most highly expressed gene from the entire list, TNFAIP6, almost 280-fold higher expressed in large follicles (Table 2 and Additional file 5: Figure S3). The up-regulated molecules which bind matrix or stabilise intercellular attachment, are represented by the tetraspanins 2 and 9 (TSPAN2, TSPAN9), the Rho GTPase activating proteins17 and -18 (ARHGAP17, ARHGAP18), and the wellknown cell surface antigens, integrin $\beta 5$ (ITGB5) and VCAM1, amongst others. Integrin $\beta 5$ is expressed in mature follicles in the mouse [52] and it is known that integrins bind extracellular matrix and can mediate cell migration, replication or apoptosis [53]. VCAM1 expression has not previously been associated with granulosa cells in follicle development. It is generally expressed in endothelial cells but can be expressed in other epithelia and promote adhesion of circulating inflammatory cells [54], and thus may also participate in the ovulatory process.

\section{Proteolysis and inhibition}

There are 13 up-regulated transcripts that encode enzymes which collectively encompass a broad range of proteolytic activities (Table 2) in large follicles. Two highlyexpressed transcripts are encoded by the serine protease 23 (PRSS23) and tissue plasminogen activator (PLAT) genes. This group includes several members of the ADAM family of metalloproteases: $A D A M 9, A D A M 10, A D A M 12$ and $A D A M T S 4$. Three well known protease inhibitor genes, TIMP1, TIMP2 and SERPINA5, are also abundantly expressed. Although it is known that ADAMTS1 plays a role in matrix remodelling and is important for ovulation in the mouse [55], horse [56] and human [57] and ADAM8 is regulated by progesterone and luteinising hormone [58], there is little evidence to date concerning the function of ADAM metalloproteases 9,10 and 12 in the ovarian follicle. These three proteases together are capable of degrading fibronectin and collagen IV, and shed Fas and kit ligand from epithelial cells in vitro [59] and thus may regulate the breakdown of matrix and differentiation of granulosa cells prior to ovulation. The inhibitors of matrix metalloproteases, TIMP 1 and 2 are also critical players in the breakdown of matrix close to the time of ovulation $[60,61]$ and can promote progesterone synthesis. An important feature of future studies will be to comprehensively map the spatio-temporal expression of these proteins in the extracellular matrix, and determine the biological effect of their accumulation.

\section{Genes activated in small versus large follicles}

Table 3 shows several important cytokine and receptor genes which have lower expression in large follicles including KIT, PDGFC (Figure 5B), FGFR2, F2RL2, IL33, IL20RA, 
and ANGPT2. Other interesting highly down regulated genes of various functions include the developmental genes: MEST (the most down regulated in large follicles, 28-fold), $I H H$ (also Figure 5B) and $M Y C$, and also JAKMIP1, which participates in cell polarisation.

Two of the genes mentioned before, $\operatorname{KIT}[62,63]$ and $A M H$ [64], are associated with follicle survival and maturation. The imprinted gene MEST which is mesodermally expressed in early embryos [65], is also strongly up regulated in small follicles. This developmental gene has been shown to be highly expressed in oocytes compared with cumulus cells [66], but not necessarily throughout the membrana granulosa. $I H H$, one of the hedgehog-signalling family genes found here to be up regulated in small follicles, has been shown to be necessary for proper egg chamber formation in Drosophila [67], and is hormonally regulated and associated with co-maturation of the theca interna in the mammalian ovary [68]. Both $\mathrm{IHH}$ and MEST may be necessary for the maintenance of an immature granulosa cell phenotype in small follicles. Interestingly, a related hedgehog family member Sonic Hedgehog Homolog (Shh) has also been reported to be regulated by heparan sulphate proteoglycan binding [69]. These molecules exist in abundance within antral follicles in the form of syndecan and glypican (cumulus cells) [70] and perlecan (between mural granulosa cells) [27], and it is possible that they may play a role at this stage of follicle development.

\section{Upstream regulator analyses}

IPA Upstream Regulator analysis was used to identify upstream transcriptional regulators and the results are shown in Table 4 . The validity and usefulness of such analyses is shown by the identification of known important pathways or molecules affecting follicle growth or granulosa cell function such as the gonadotrophin/ protein kinase pathways (with identified upstream regulators including chorionic gonadotrophin, follicle-stimulating hormone, forskolin, 8-bromo cAMP, bucladesine which is a cell permeable cAMP analogue, epidermal growth factor pathway (ERBB2), renin angiotensin system (lorsartan which is an inhibitor of the angiotensin Type II receptor), oestradiol (tamoxifen;), leptin (LEPR), inhibin (INHBA), GATA transcription factors (GATA6), , VEGF, retinoid action (AGN194294 which is an RXR ligand), lipid metabolism (APOE,) and the aryl hydrocarbon (AH) receptor (tetrachlorodibenzodioxin).

Two molecules which have not been well studied in relation to follicular development appear to significantly alter transcription in large follicles: XBP1 and STAT4 (Figure 6). $\mathrm{XBP} 1$ is cleaved to an activated form under conditions of endoplasmic reticulum stress and subsequently stimulates the expression of a number of chaperones resulting in removal of misfolded proteins and targets them for degradation [71]. It is predicted to be up regulated, and it is possible that radical oxygen species generated by the steroidogenic process may contribute to the misfolding of proteins [72]. STAT4 is also predicted to be up regulated in large follicles, and is a mediator of the interleukin -12 immune response [73,74], and further supports the involvement of inflammatory processes detected within the follicle at this time as indicated by the IPA and GO enrichment analyses.

A new pathway or molecule identified by IPA Upstream Regulator analyses is MGEA5 (meningioma expressed antigen 5) which was down regulated in large follicles (Figure 6). There is a diverse set of about 600 proteins known to be post-translationally modified by the addition of O-linked $\mathrm{N}$-acetylglucosamine (O-GlcNAc) to their serine and threonine residues by the action of the enzyme O-GlcNAc transferase (OGT/Sxc) [75]. MGEA5 encodes beta- $N$-acetylglucosaminidase (O-GlcNAcase), whose catalytic activity removes $\mathrm{O}-\mathrm{GlcNAc}$ from serine and threonine residues in proteins [75]. This cycling of O-GlcNAc to posttranslationally modify proteins can therefore regulate the activity of these proteins. O-linked glycosylation has been observed in bovine cumulus cells and linked to the availability of nutrients for the fuel-sensing hexosamine biosynthetic pathway [76,77]. The hexosamine biosynthetic pathway is sensitive to the levels of lipid, glucose and amine which together supply components of O-GlcNAc. Flux in nutrients thereby modulates protein activity by flux in O-linked glycosylation of proteins. Down regulation of MGEA5 in large follicles suggests that in small follicles there is decreased O-linked glycosylation of proteins and indeed increased O-linked glycosylation of proteins has been observed to be negative for the success of oocyte maturation [76,77].

\section{Conclusions}

In conclusion, substantial changes occur in gene expression in granulosa cells as follicles enlarge from small to large antral sizes. Gene expression becomes less variable, and the processes of axonal guidance, immune signalling and cell rearrangement were most affected in large follicles. Some important networks were associated with: (A) Notch, SLIT/ROBO and PI3K signalling, and (B) ITGB5 and extracellular matrix signalling through extracellular signal related kinases (ERKs). Upstream regulator genes which were predicted to be active in large follicles include STAT4 and $X B P 1$, whereas $M G E A 5$ was predicted to be inhibited. The latter encodes an enzyme that modifies the activity of many target proteins, including those involved in energy sensing, by removal of $\mathrm{N}$-acetylglucosamine from serine and threonine residues. By comparison, developmental processes such as those stimulated by $K I T, I H H$ and MEST were most active in small follicles. 
Table 4 Upstream regulators predicted to be activated or inhibited in large follicles compared with small follicles, using the 3-fold differentially-regulated data set with FDR $\boldsymbol{P}<\mathbf{0 . 0 5}$, on the basis of known interactions compiled in the IPA Upstream Regulator analysis

\begin{tabular}{|c|c|c|c|c|}
\hline Upstream regulator & Molecule type & $\begin{array}{l}\text { *Activation } \\
\text { z-score }\end{array}$ & $\begin{array}{l}\text { **P-value } \\
\text { of overlap }\end{array}$ & Target genes in the data set \\
\hline \multicolumn{5}{|c|}{ Predicted activated molecules/genes } \\
\hline Tacrolimus & Chemical drug & 3.302 & $2.1 \times 10^{-2}$ & ABLIM1, ACTA1, CDK13, COL1A1, CYBB, FOS, ID3, IL33, MYC, PDCD4, PTGS2 \\
\hline STAT4 & Transcription regulator & 3.300 & $4.8 \times 10^{-2}$ & AKAP8L, ARFGAP3, ERRFI1, GLG1, IER3, MGARP, PYGL, RCN3, RNF128, SF3B1, WHSCIL1 \\
\hline Chorionic gonadotrophin & Hormone & 3.224 & $2.4 \times 10^{-9}$ & $\begin{array}{l}\text { ABCB1, AKR1C3, CDH2, CLU, CYP11A1, CYP19A1, F2RL1, HSD3B2, IER3, IGFBP4, IL33, ILAR, INHBA, } \\
\text { ITGBS, LGALS3BP, LHCGR, MTPN, NPR3, NR5A2, NRP1, PFKFB3, PGR, PLAT, PPAP2B, PTGFR, PTGS2, } \\
\text { SFRP4, STAR, TIMP1, TNFAIPG, VCAN }\end{array}$ \\
\hline XBP1 & Transcription regulator & 2.887 & $1.5 \times 10^{-3}$ & $\begin{array}{l}\text { APBB2, APOA1, ARFGAP3, COPZ1, DERL1, EDEM2, GOLGA4, HERPUD1, HM13, HMOX1, } \\
\text { MYC, RCN3, RRT1, SEC63, VCAM1 }\end{array}$ \\
\hline FSH & Hormone & 2.759 & $1.8 \times 10^{-4}$ & $\begin{array}{l}\text { ACTA1, BCL2L2, BMPR1A, BMPR2, CDH2, CITED1, CYP11A1, CYP19A1, FOS, GRK5, HSD3B2, IGFBP4, } \\
\text { INHBA, ITGBS, LHCGR, MAPKG, MYC, NOL3, PGR, PLAT, PTGS2, RPRM, STAR, TIMP1, TIMP2, TNFAIPG, TOB1 }\end{array}$ \\
\hline FOXO3 & Transcription regulator & 2.613 & $7.4 \times 10^{-2}$ & EIF4EBP1, FGFR2, GABARAPL1, GADD45B, IER3, MYC, SLC4OA1, TXNIP \\
\hline AGN194204 & Chemical drug & 2.550 & $2.4 \times 10^{-3}$ & ANAPC5, BZW2, CLIC4, FDFT1, IL4R, KLF6, MAN1A1, MYC, PDCD4, RCAN3, STIM1, STRA6, TIMP1 \\
\hline Forskolin & Chemical toxicant & 2.444 & $3.4 \times 10^{-5}$ & $\begin{array}{l}\text { ACTA1, APOA1, ATP6V1A, CARTPT, CDH2, CLU, COLIA1, CYP11A1, CYP19A1, FOS, GRK5, HMOX1, HSD3B2, } \\
\text { ID2, ID3, IGFBPG, INHBA, ITGBS, LARGE, LHCGR, LTF, MYC, NOL3, NTSE, PGR, PLAT, PTGS2, PTHLH, RABTA, } \\
\text { RPRM, SCG 2, STAR, TIMP1, TNFAIPG, TXNIP, VCAN }\end{array}$ \\
\hline INHBA & Growth factor & 2.389 & $3.2 \times 10^{-2}$ & CPNE8, CYP11A1, CYP19A1, DTNA, INHBA, LHCGR, PRPF38B, STAR, TIMP1 \\
\hline GATA6 & Transcription regulator & 2.377 & $5.6 \times 10^{-3}$ & BMPR2, CYP11A1, CYP19A1, HSD3B2, LHCGR, STAR \\
\hline 8-bromo-cAMP & Chemical reagent & 2.287 & $2.1 \times 10^{-4}$ & APOA1, CLU, CYP11A1, CYP19A1, FOS, HSD3B2, LHCGR, MYC, PGR, PLAT, PTGFR, PTGS2, STAR, TIMP1, TIMP2 \\
\hline Bucladesine & Chemical toxicant & 2.166 & $1.0 \times 10^{-4}$ & $\begin{array}{l}\text { CDH2, CLU, CYP11A1, CYP19A1, ENPP1, ERRFI1, F3, FOS, GADD45B, HMOX1, HSD3B2, IGFBP6, } \\
\text { KIT, MYC, PTGS2, QSOX1, RGN, SCG2, STAR, TIMP1, TIMP2 }\end{array}$ \\
\hline Vegf & Cytokine & 2.008 & $2.6 \times 10^{-4}$ & $\begin{array}{l}\text { ABCB1, ADAM10, ANGPT2, ANGPTL2, BMP2K, F3, GRK5, HES1, HMOX1, IGFBP4, INHBA, LPHN2, } \\
\text { LRP8, MYC, NOTCH1, NR5A2, NRP1, PPAP2B, PTGS2, PTHLH, TIMP1, TRIB2, VCAM1 }\end{array}$ \\
\hline \multicolumn{5}{|c|}{ Predicted inhibited molecules/genes } \\
\hline LEPR & Transmembrane receptor & -2.000 & $7.2 \times 10^{-2}$ & APOA1, APOA2, CARTPT, COL1A1, COL4A1, FOS, TIMP1 \\
\hline Losartan potassium & Chemical drug & -2.035 & $6.4 \times 10^{-6}$ & AQP1, COL1A1, CYBB, F3, FOS, GRK5, ITGB5, PTGS2, PTHLH, STAR, TIMP1, VCAM1 \\
\hline APOE & Transporter & -2.035 & $2.5 \times 10^{-5}$ & $\begin{array}{l}\text { APOA1, CLU, COL1A1, CTSB, CYBB, F2R, F2RL1, F3, GPR77, GPX3, HMOX1, IGFBP6, } \\
\text { LRP8, MYO1B, NPNT, PPAP2B, PTGS2, TIMP1, VCAM1 }\end{array}$ \\
\hline Tetrachlorodi-benzodioxin & Chemical toxicant & -2.038 & $7.2 \times 10^{-2}$ & $\begin{array}{l}\text { ABCB1, CYP11A1, CYP19A1, FOS, HES1, HMOX1, INSIG2, LHCGR, } \\
\text { MYC, MYO10, PTGFR, PTGS2, PTPN13, SLC4OA1, SPOCK2, STAR }\end{array}$ \\
\hline NROB1 & Ligand-dependent nuclear receptor & -2.092 & $2.0 \times 10^{-4}$ & CYP11A1, CYP19A1, HSD3B2, NR5A2, STAR \\
\hline Tamoxifen & Chemical drug & -2.241 & $4.5 \times 10^{-3}$ & CDH11, CLU, EPHX1, F2R, FHL2, FOS, HES1, IER3, IGFBP4, MYC, PGR, PTGS2, UGCG \\
\hline MGEA5 & Enzyme & -2.500 & $1.9 \times 10^{-3}$ & $\begin{array}{l}\text { ABLIM1, ACSS2, CMTM8, CREB3L2, FDFT1, FERMT2, IGFBP4, IL2ORA, IL6R, ITGB5, } \\
\text { LPHN2, MYO10, PFKM, PPAP2B, TIMP1, TIMP2 }\end{array}$ \\
\hline ERBB2 & Kinase & -3.304 & & $\begin{array}{l}\text { ACTA1, ADAM12, ANGPTL2, ATP6V1A, BEX2, CDH11, CHCHD10, CHST10, CLU, COL1A1, COLAA1, CUL1, CUL3, } \\
\text { DERL1, EIFAEBP1, F2R, FOS, GPX3, HES1, ID2, IGFBP4, IGFBPG, KIT, LAMC2, MAN1A1, MAOA, MFAP2, MYC, MYO10, } \\
\text { NDRG4, NEDD9, NOTCH1, NPNT, NRP1, PDCD4, PDLIM4, PFKFB3, PLAT, PTGS2, TGIFI, VCAN }\end{array}$ \\
\hline
\end{tabular}

*The bias-corrected z-score is used to infer the activation states of transcriptional regulators. It is calculated from the proportions of genes which are differentially regulated in an expected direction based on the known interactions between the regulator and the genes present in the Ingenuity database. Those genes with a z-score greater or less than two are considered to be either activated or inhibited respectively. **The $P$ value of overlap is the calculated statistical significance of overlap between genes from the dataset and genes that are known to be regulated by the upstream regulator using Fisher's exact test. 


\section{A}

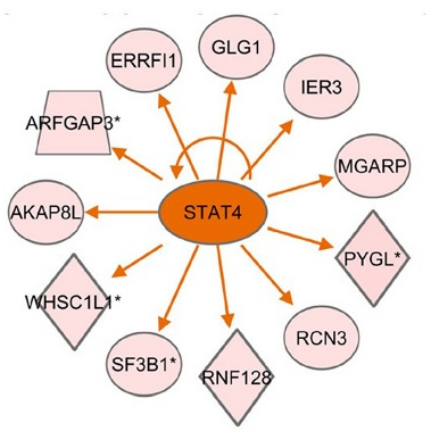

B

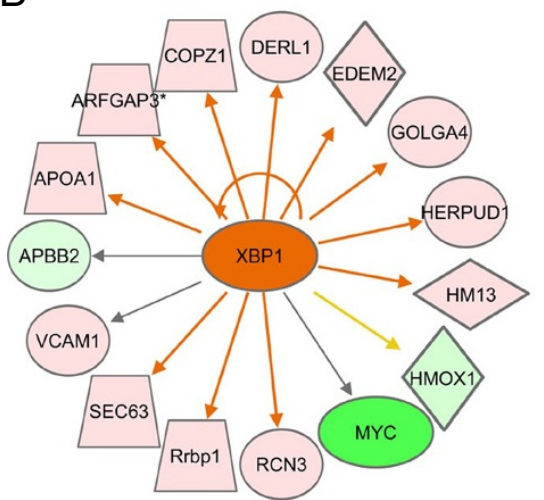

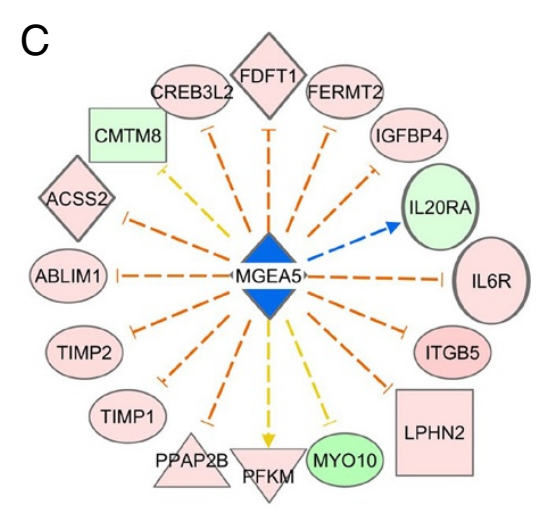

Figure 6 Two upstream regulators of interest, STAT4 (A) and XBP1 (B), which are predicted to be activated and one regulator, MGEA5 (C), predicted to be inhibited in large follicles based on known interactions with genes in our data set by IPA. Interactions between molecules are shown as explained in the legend, with focus molecule symbols highlighted in color, based on up (red) or down (green) regulation in large follicles and of increasing intensity with degree of fold change. The suggested action of the central gene is indicated as up-(red) or down-(blue) regulating with the degree of confidence increasing with color intensity. Arrowheads at the end of interactions indicate activation, whereas bars indicate inhibitory effects. The unbroken arrows and the dashed arrows represent direct and indirect interactions respectively, between the genes and the upstream regulators.

\section{Methods}

For these experiments bovine ovaries were collected as pairs at a local abattoir in South Australia from nonpregnant Bos taurus cows, within 20 min of slaughter and transported to the laboratory on ice. Ovary pairs were macroscopically examined for the presence of a corpus luteum to exclude ovaries from non-cycling cows, and large cystic follicles were discarded. Both small ( $\leq 5 \mathrm{~mm}$ in diameter, $\mathrm{n}=10)$ and large (>12 mm, $\mathrm{n}=4)$ follicles were selected randomly from different animals. The follicles were dissected from each ovary and the diameter measured with the aid of an ocular micrometer. A portion of each follicle, approximately $100 \mathrm{~mm}^{3}$, was removed and fixed in $2.5 \%$ glutaraldehyde in $0.1 \mathrm{M}$ phosphate buffer $(\mathrm{pH} 7.25)$ for subsequent classification of health or atresia, and granulosa cells were collected from the remaining follicle wall. Only healthy follicles were analysed in this study.

\section{Histological classification of follicles}

Following fixation overnight, the portions of each ovary were rinsed several times with buffer and post-fixed in
$2 \%(\mathrm{v} / \mathrm{v})$ aqueous osmium tetroxide for $1 \mathrm{~h}$ at $4^{\circ} \mathrm{C}$, as described previously [78]. For light microscopic examination of all follicles, $1 \mu \mathrm{m}$-thick epoxy sections were cut using glass knives and a Richert-Jung Ultracut E ultramicrotome (Leica Microsystems Pty. Ltd., VIC, Australia), stained with $1 \%(\mathrm{w} / \mathrm{v})$ aqueous methylene blue and examined using an Olympus BX50 microscope (Olympus Australia Pty. Ltd, VIC, Australia). Healthy and atretic follicles were identified as described previously $[18,19]$ and all healthy follicles, both large and small, selected for the current experiments had no dead or dying granulosa cells. The small follicle phenotype was sub-classified into two types, rounded or columnar, based on the shape of the basally-situated granulosa cells $[79,80]$.

\section{Isolation of granulosa cells}

Following removal of a portion of tissue for microscopic examination, each follicle was transferred to a $35 \mathrm{~mm}$ Petri dish containing $1.0 \mathrm{ml}$ Hank's balanced-salt solution (HBSS) without calcium or magnesium. The granulosa cell 
layer was removed by gentle rubbing with a glass Pasteur pipette, previously modified by heat sealing the tip into a rounded smooth surface. The HBSS containing the granulosa cells were centrifuged at $500 \times$ g for $7 \mathrm{~min}$ at $4^{\circ} \mathrm{C}$, the medium was removed by aspiration and the cells washed twice in phosphate-buffered saline. Finally the cells were resuspended in RNAlater (Ambion, Austin, TX, USA), and stored at $-20^{\circ} \mathrm{C}$ until required.

\section{RNA isolation}

Total RNA was extracted from the granulosa cells of 10 small and 4 large healthy follicles using RNeasy mini kits (Qiagen). The concentration of the RNA was determined by spectrophotometric measurement at $260 \mathrm{~nm}$. For each granulosa cell preparation, $5 \mu \mathrm{g}$ of RNA was treated with DNA-free (Ambion) according to the manufacturer's instructions.

\section{Real time RT-PCR}

Synthesis of cDNA and quantitative Reverse Transcriptase Polymerase Chain Reaction (RT-PCR) using plasmid standards were performed as previously [81] and briefly described here. Total RNA (500 ng) was reverse transcribed with SuperScriptIII (Life Technologies, Carlsbad, Ca, USA) using random hexamer primers (Geneworks, Thebarton, SA, Australia) according to the manufacturer's instructions. The program Primer Express was used to design primers to the bovine sequences of ribosomal 18S, CYP17A1 and CYP19A1 (Table 5). An ABI Prism 7000 Sequence Detection System (Applied Biosystems, CA, USA) was used for real time RT-PCR detection with SYBR Green (Eppendorf, Hamburg, Germany) and 10 pmoles of forward and reverse primers in a $20 \mu \mathrm{l}$ reaction. The amplification conditions are described in Table 5. Plasmid standards were generated by cloning amplified products into pCR2.1-TOPO vector (Life Technologies), then transformed into E. coli XL1 Blue (Agilent Technologies), extracted and purified. These standards were quantitated by Absorbance at $260 \mathrm{~nm}$ and serially diluted over 3 logs then amplified together with the diluted sample cDNA in the real time reaction to determine quantities of RNA expressed as fg/ng $18 \mathrm{~S}$ ribosomal RNA.

\section{Microarray profiling}

Following confirmation of the quality of the RNA and cDNA synthesis, hybridisations to GeneChip Bovine Genome Arrays (Affymetrix, CA, USA) and scanning were performed according to Affymetrix protocols at the Australian Genome Research Facility (Walter \& Eliza Hall Institute of Medical Research, Parkville, VIC, Australia) as previously [82] and briefly described below. All samples were analysed together using the same batch of arrays. In brief, the starting amount of total RNA for each probe preparation varied between 2 to $5 \mu \mathrm{g}$. First-strand cDNA synthesis was performed using a T7-linked oligo-dT primer, followed by second strand synthesis. In vitro transcription reactions were performed in batches to generate biotinylated cRNA targets, which were subsequently chemically fragmented at $95^{\circ} \mathrm{C}$ for $35 \mathrm{~min}$. Twenty $\mu \mathrm{g}$ of the fragmented, biotinylated cRNA was hybridised at $45^{\circ} \mathrm{C}$ for $16 \mathrm{~h}$ to Affymetrix GeneChip Bovine Genome Arrays, which contained 24,128 probe sets representing over 23,000 transcripts and variants, including 19,000 UniGene clusters. The arrays were then washed and stained with streptavidin-phycoerythrin (final concentration $10 \mu \mathrm{g} / \mathrm{ml}$ ). Signal amplification was achieved by using a biotinylated anti-streptavidin antibody. The array was then scanned according to the manufacturer's instructions. The scanned images were inspected for the presence of any defect on the array.

\section{Data normalisation and analyses}

To minimise discrepancies due to variables such as sample preparation, hybridisation conditions, staining, or array lot, the raw expression data was normalised using the RMA background correction (Robust Multi-array average [83]) with quantile normalisation, log base 2 transformation and mean probe set summarisation with adjustment for GC content and performed in Partek Genomics Suite Software version 6.5 (Partek Incorporated, St Louis, MO, USA). All samples sent for analysis passed all quality controls during analysis. The arrays were analysed as part of a larger set of CEL files which additionally included samples of granulosa RNA from 5 atretic follicles as discussed elsewhere [82]. For initial statistical analysis, the data were first subjected to Principal Component Analysis (PCA, based on the method

Table 5 Primers and conditions used for quantitative RT-PCR

\begin{tabular}{|c|c|c|c|}
\hline Target & Primer sequences 5'-3' & Genbank accession number & PCR reaction and conditions \\
\hline \multirow[t]{2}{*}{ CYP19A1 } & Forward ggctatgtggacgtgttgacc & NM_174305 & $2 \min 50 C, 10 \min 95 C, 40 \times$ cycles of $15 \mathrm{~s} 95 \mathrm{C}$ and $60 \mathrm{~s} 60 \mathrm{C}$ \\
\hline & Reverse tgagaaggagagcttgccatg & & \\
\hline \multirow[t]{2}{*}{ CYP17A1 } & Forward accatcagagaagtgctccgaa & NM_174304 & $2 \min 50 C, 10 \min 95 C, 40 \times$ cycles of $15 \mathrm{~s} 95 \mathrm{C}$ and $60 \mathrm{~s} 60 \mathrm{C}$ \\
\hline & Reverse ccacaacgtctgtgcctttgt & & \\
\hline \multirow[t]{2}{*}{185} & Forward agaaacggctaccacatccaa & DQ2224 & $2 \min 50 C, 10 \min 95 C, 40 \times$ cycles of $15 \mathrm{~s} 95 \mathrm{C}$ and $60 \mathrm{~s} 60 \mathrm{C}$ \\
\hline & Reverse cctgtattgttatttttcgt & & \\
\hline
\end{tabular}


of [84]) and hierarchical clustering analysis to compare the gene expression patterns of the arrays in terms of our classification. Hierarchical clustering was performed using the Euclidian algorithm for dissimilarity with average linkage. The expression data were analysed by ANOVA using method of moments estimation [85] with post-hoc FDR test for multiple comparisons. The fold change in expression for each gene was based on the non log-transformed values after correction and normalisation. A differentially-expressed gene data set was imported into IPA and genes mapped against the Ingenuity Knowledge Base for network and pathway analysis. These differentially-expressed genes were further annotated and classified based on the GO consortium annotations from the GO Bos taurus database (2010/02/ 24) [86] using GOEAST [87]). The background for the gene enrichment analyses in IPA and GOEAST was the whole array. Statistical association for mapping of genes to functions and pathways in IPA was conducted using a Fisher's right tailed $t$-test and similarly ranking of mapping to GO terms in GOEAST was accomplished by the Benjamini-Yuketeli method. Expression data were also exported to Excel and used to generate size-frequency distributions of the coefficient of variation for each probe set for small and large follicles. We also used IPA Upstream Regulator analysis to identify upstream transcriptional regulators by Fisher's exact $t$-test. The analytical outcome is based upon prior knowledge of expected effects between transcriptional regulators and target genes stored in the Ingenuity Knowledge Base. The microarray CEL files, normalised data and experimental information have been deposited in the GEO database under series record GSE39589.

\section{Additional files}

Additional file 1: Figure S1. Unsupervised hierarchical clustering across all probe sets $(n=24,182)$ for 14 arrays using the Euclidian dissimilarity algorithm method with average linkage in Partek. The heatmap represents the distribution of normalised signal intensity, grouping by pattern similarity for both probe set and array. The $\mathrm{R}$ columns represent the rounded granulosa cells and the $C$ columns represent the columnar granulosa cell arrays.

Additional file 2: Figure S2. Plots of coefficients of variation (CV) versus their frequency for granulosa cell cDNA hybridised to Bovine Genome Affymetrix Expression arrays across replicate samples per gene for small $(n=10)$ and large follicles $(n=4)$. The $50 \%$ most highly expressed genes, representing half of all probe sets $(n=12,064)$ were used in these analyses. 2 fold and 3 fold represent all probe sets which were 2 -fold $(n=1809)$ or 3 -fold $(n=598)$ differentially regulated between small and large follicles in Partek.

Additional file 3: Table S1. The total number of probe sets (758) which were 3 -fold differentially regulated with a Benjamini-Hochberg FDR multiple correction of $P<0.05$ between large and small healthy follicles listed in alphabetical order by gene symbol.

Additional file 4: Figure S3. The complete canonical Axonal Guidance Signalling pathway as presented in IPA showing which genes map from the 3-fold differentially-expressed dataset with a Benjamini-Hochberg FDR multiple correction $P<0.05$ between large and small healthy follicles. Genes which are up regulated in large are indicated in red, and those which are down regulated are green, with the degree of fold difference commensurate with the color intensity.

Additional file 5: Figure S4. The complete canonical IL-6 signalling pathway as presented in IPA showing which genes map from the 3-fold differentially-expressed dataset with a Benjamini-Hochberg FDR multiple correction $P<0.05$ between small and large healthy follicles. Genes which are up-regulated in large are indicated in red, and those which are down-regulated are green, with the degree of fold difference commensurate with the color intensity.

\section{Abbreviations}

FDR: Benjamini-Hochberg false discovery rate; GO: Gene ontology; GOEAST: Gene ontology enrichment analysis software toolkit; GEO: Gene expression omnibus; HBBS: Hank's balanced-salt solution; IPA: Ingenuity pathway analysis; O-GlcNAc: O-linked N-acetylglucosamine; PCA: Principal component analysis; RMA: Robust multi-array average; RT-PCR: Reverse transcriptase polymerase chain reaction.

\section{Competing interests}

No competing interest, financial or otherwise, are declared by the authors.

\section{Authors' contributions}

Conceived and designed the experiments: HFI-R, RJR. Performed the experiments: $\mathrm{NH}, \mathrm{KH}, \mathrm{HFI}-\mathrm{R}, \mathrm{MLH}$, SEM. Analysed the data: $\mathrm{NH}, \mathrm{KH}$, RJR. Contributed reagents/materials/analysis tools: $\mathrm{NH}, \mathrm{KH}, \mathrm{RJR}$. Wrote the paper: $\mathrm{NH}, \mathrm{KH}, \mathrm{HFI-R}$, RJR. All authors read and approved the final manuscript.

\section{Acknowledgements}

We thank Drs Richard D'Andrea, Thomas Ohnesorg, Andrew Sakko, Yi Peng, Anand Venkatraman, David Adelson, Cristin Print, Angela Chang and William Rainey for their discussions and earlier contributions to this study and T\&R Pastoral for donation of ovaries. This work was supported by the National Health and Medical Research Council of Australia, the Australian Research Council and the University of Adelaide.

\section{Author details}

'Research Centre for Reproductive Health, Discipline of Obstetrics and Gynaecology, School of Paediatrics and Reproductive Health, Robinson Institute, University of Adelaide, Adelaide, SA 5005, Australia. ${ }^{2}$ Current Address: School of Medical Science, Griffith University, Gold Coast, Queensland, Australia.

Received: 30 June 2013 Accepted: 2 January 2014 Published: 14 January 2014

\section{References}

1. Rodgers RJ, Lavranos TC, van Wezel IL, Irving-Rodgers HF: Development of the ovarian follicular epithelium. Mol Cell Endocrinol 1999, 151(1-2):171-179.

2. Rodgers RJ, Irving-Rodgers HF: Formation of the ovarian follicular antrum and follicular fluid. Biol Reprod 2010, 82(6):1021-1029.

3. Ginther OJ, Wiltbank MC, Fricke PM, Gibbons JR, Kot K: Selection of the dominant follicle in cattle. Biol Reprod 1996, 55(6):1187-1194.

4. Fortune JE, Sirois J, Turzillo AM, Lavoir M: Follicle selection in domestic ruminants. J Reprod Fertil Supp/ 1991, 43:187-198.

5. Ginther OJ, Bergfelt DR, Beg MA, Kot K: Follicle selection in cattle: relationships among growth rate, diameter ranking, and capacity for dominance. Biol Reprod 2001, 65(2):345-350.

6. Manikkam M, Calder MD, Salfen BE, Youngquist RS, Keisler DH, Garverick HA: Concentrations of steroids and expression of messenger RNA for steroidogenic enzymes and gonadotropin receptors in bovine ovarian follicles of first and second waves and changes in second wave follicles after pulsatile LH infusion. Anim Reprod Sci 2001, 67(3-4):189-203.

7. Beg MA, Bergfelt DR, Kot K, Wiltbank MC, Ginther OJ: Follicular-fluid factors and granulosa-cell gene expression associated with follicle deviation in cattle. Biol Reprod 2001, 64(2):432-441.

8. Matti N, Irving-Rodgers HF, Hatzirodos N, Sullivan TR, Rodgers RJ: Differential expression of focimatrix and steroidogenic enzymes before size deviation 
during waves of follicular development in bovine ovarian follicles. Mol Cell Endocrinol 2010, 321(2):207-214.

9. Irving-Rodgers $\mathrm{HF}$, Harland ML, Rodgers $\mathrm{RJ}$ : A novel basal lamina matrix of the stratified epithelium of the ovarian follicle. Matrix Biol 2004, 23(4):207-217.

10. Rodgers HF, Irvine CM, van Wezel IL, Lavranos TC, Luck MR, Sado Y, Ninomiya Y, Rodgers RJ: Distribution of the alpha1 to alpha6 chains of type IV collagen in bovine follicles. Biol Reprod 1998, 59(6):1334-1341.

11. McArthur ME, Irving-Rodgers HF, Byers S, Rodgers RJ: Identification and immunolocalization of decorin, versican, perlecan, nidogen, and chondroitin sulfate proteoglycans in bovine small-antral ovarian follicles. Biol Reprod 2000, 63(3):913-924.

12. Evans AC, Ireland JL, Winn ME, Lonergan P, Smith GW, Coussens PM, Ireland JJ: Identification of genes involved in apoptosis and dominant follicle development during follicular waves in cattle. Biol Reprod 2004, 70(5):1475-1484.

13. Mihm M, Baker PJ, Fleming LM, Monteiro AM, O'Shaughnessy PJ: Differentiation of the bovine dominant follicle from the cohort upregulates mRNA expression for new tissue development genes. Reproduction 2008, 135(2):253-265

14. Skinner MK, Schmidt M, Savenkova MI, Sadler-Riggleman I, Nilsson EE: Regulation of granulosa and theca cell transcriptomes during ovarian antral follicle development. Mol Reprod Dev 2008, 75(9):1457-1472.

15. Liu Z, Youngquist RS, Garverick HA, Antoniou E: Molecular mechanisms regulating bovine ovarian follicular selection. Mol Reprod Dev 2009, 76(4):351-366.

16. Walsh SW, Mehta JP, McGettigan PA, Browne JA, Forde N, Alibrahim RM, Mulligan FJ, Loftus B, Crowe MA, Matthews D, et al: Effect of the metabolic environment at key stages of follicle development in cattle: focus on steroid biosynthesis. Physiol Genomics 2012, 44(9):504-517.

17. Christenson LK, Gunewardena S, Hong X, Spitschak M, Baufeld A, Vanselow $J$ : Research resource: preovulatory lh surge effects on follicular theca and granulosa transcriptomes. Mol Endocrinol 2013, 27(7):1153-1171.

18. Irving-Rodgers HF, van Wezel IL, Mussard ML, Kinder JE, Rodgers RJ: Atresia revisited: two basic patterns of atresia of bovine antral follicles. Reproduction 2001, 122(5):761-775.

19. Rodgers RJ, Irving-Rodgers HF: Morphological classification of bovine ovarian follicles. Reproduction 2010, 139(2):309-318.

20. Irving-Rodgers HF, Harland ML, Sullivan TR, Rodgers RJ: Studies of granulosa cell maturation in dominant and subordinate bovine follicles: novel extracellular matrix focimatrix is co-ordinately regulated with cholesterol side-chain cleavage CYP11A1. Reproduction 2009, 137(5):825-834

21. Rodgers RJ, Rodgers HF, Hall PF, Waterman MR, Simpson ER: Immunolocalization of cholesterol side-chain-cleavage cytochrome P-450 and 17 alpha-hydroxylase cytochrome P-450 in bovine ovarian follicles. J Reprod Fertil 1986, 78(2):627-638.

22. Xu Z, Garverick HA, Smith GW, Smith MF, Hamilton SA, Youngquist RS: Expression of follicle-stimulating hormone and luteinizing hormone receptor messenger ribonucleic acids in bovine follicles during the first follicular wave. Biol Reprod 1995, 53(4):951-957.

23. Peng XR, Hsueh AJ, LaPolt PS, Bjersing L, Ny T: Localization of luteinizing hormone receptor messenger ribonucleic acid expression in ovarian cell types during follicle development and ovulation.

Endocrinology 1991, 129(6):3200-3207.

24. Horie K, Takakura K, Fujiwara H, Suginami H, Liao S, Mori T: Immunohistochemical localization of androgen receptor in the human ovary throughout the menstrual cycle in relation to oestrogen and progesterone receptor expression. Hum Reprod 1992, 7(2):184-190.

25. Sisco B, Pfeffer PL: Expression of activin pathway genes in granulosa cells of dominant and subordinate bovine follicles. Theriogenology 2007, 68(1):29-37.

26. Fan HY, Liu Z, Johnson PF, Richards JS: CCAAT/enhancer-binding proteins (C/EBP)-alpha and -beta are essential for ovulation, luteinization, and the expression of key target genes. Mol Endocrinol 2011, 25(2):253-268

27. Irving-Rodgers HF, Rodgers RJ: Extracellular matrix of the developing ovarian follicle. Semin Reprod Med 2006, 24(4):195-203.

28. Knight PG, Glister C: TGF-beta superfamily members and ovarian follicle development. Reproduction 2006, 132(2):191-206.

29. Myers M, Pangas SA: Regulatory roles of transforming growth factor beta family members in folliculogenesis. Wiley Interdiscip Rev Syst Biol Med 2010, 2(1):117-125.
30. Hillier SG, Yong EL, Illingworth PJ, Baird DT, Schwall RH, Mason AJ: Effect of recombinant inhibin on androgen synthesis in cultured human thecal cells. Mol Cell Endocrinol 1991, 75(2):R1-R6

31. Lewis KA, Gray PC, Blount AL, MacConell LA, Wiater E, Bilezikjian LM, Vale W: Betaglycan binds inhibin and can mediate functional antagonism of activin signalling. Nature 2000, 404(6776):411-414

32. McNatty KP, Juengel JL, Reader KL, Lun S, Myllymaa S, Lawrence SB, Western A, Meerasahib MF, Mottershead DG, Groome NP, et al: Bone morphogenetic protein 15 and growth differentiation factor 9 co-operate to regulate granulosa cell function in ruminants. Reproduction 2005, 129(4):481-487.

33. Bromfield JJ, Sheldon IM: Lipopolysaccharide initiates inflammation in bovine granulosa cells via the TLR4 pathway and perturbs oocyte meiotic progression in vitro. Endocrinology 2011, 152(12):5029-5040.

34. Liu Z, de Matos DG, Fan HY, Shimada M, Palmer S, Richards JS: Interleukin-6: an autocrine regulator of the mouse cumulus cell-oocyte complex expansion process. Endocrinology 2009, 150(7):3360-3368.

35. Leo CP, Pisarska MD, Hsueh AJ: DNA array analysis of changes in preovulatory gene expression in the rat ovary. Biol Reprod 2001, 65(1):269-276

36. Roach LE, Petrik JJ, Plante L, LaMarre J, Gentry PA: Thrombin generation and presence of thrombin receptor in ovarian follicles. Biol Reprod 2002, 66(5):1350-1358.

37. Fernandis AZ, Ganju RK: Slit: a roadblock for chemotaxis. Sci STKE 2001, 2001(91):e1.

38. Fortini ME: Notch signaling: the core pathway and its posttranslational regulation. Dev Cell 2009, 16(5):633-647.

39. Dickinson RE, Hryhorskyj L, Tremewan H, Hogg K, Thomson AA, McNeilly AS, Duncan WC: Involvement of the SLIT/ROBO pathway in follicle development in the fetal ovary. Reproduction 2010, 139(2):395-407.

40. Dickinson RE, Duncan WC: The SLIT-ROBO pathway: a regulator of cell function with implications for the reproductive system. Reproduction 2010, 139(4):697-704.

41. Zhang CP, Yang JL, Zhang J, Li L, Huang L, Ji SY, Hu ZY, Gao F, Liu YX: Notch signaling is involved in ovarian follicle development by regulating granulosa cell proliferation. Endocrinology 2011, 152(6):2437-2447.

42. Fayad T, Levesque V, Sirois J, Silversides DW, Lussier JG: Gene expression profiling of differentially expressed genes in granulosa cells of bovine dominant follicles using suppression subtractive hybridization. Biol Reprod 2004, 70(2):523-533.

43. Fayad T, Lefebvre R, Nimpf J, Silversides DW, Lussier JG: Low-density lipoprotein receptor-related protein 8 (LRP8) is upregulated in granulosa cells of bovine dominant follicle: molecular characterization and spatio-temporal expression studies. Biol Reprod 2007, 76(3):466-475.

44. Senturk A, Pfennig S, Weiss A, Burk K, Acker-Palmer A: Ephrin Bs are essential components of the Reelin pathway to regulate neuronal migration. Nature 2011, 472(7343):356-360.

45. Xu Y, Zagoura D, Keck C, Pietrowski D: Expression of Eph receptor tyrosine kinases and their ligands in human Granulosa lutein cells and human umbilical vein endothelial cells. Exp Clin Endocrinol Diabetes 2006, 114(10):590-595.

46. Cheung SM, Kornelson JC, Al-Alwan M, Marshall AJ: Regulation of phosphoinositide 3-kinase signaling by oxidants: hydrogen peroxide selectively enhances immunoreceptor-induced recruitment of phosphatidylinositol $(3,4)$ bisphosphate-binding $\mathrm{PH}$ domain proteins. Cell Signal 2007, 19(5):902-912.

47. Perlman S, Bouquin T, van den Hazel B, Jensen TH, Schambye HT, Knudsen S, Okkels JS: Transcriptome analysis of FSH and FSH variant stimulation in granulosa cells from IVM patients reveals novel regulated genes. Mol Hum Reprod 2006, 12(3):135-144.

48. Bhattacharya S, Michels CL, Leung MK, Arany ZP, Kung AL, Livingston DM: Functional role of p35srj, a novel p300/CBP binding protein, during transactivation by HIF-1. Genes Dev 1999, 13(1):64-75.

49. Yin Z, Haynie J, Yang X, Han B, Kiatchoosakun S, Restivo J, Yuan S, Prabhakar NR, Herrup K, Conlon RA, et al: The essential role of Cited2, a negative regulator for HIF-1alpha, in heart development and neurulation. Proc Natl Acad Sci U S A 2002, 99(16):10488-10493.

50. Roberts AJ, Echternkamp SE: Insulin-like growth factor binding proteins in granulosa and thecal cells from bovine ovarian follicles at different stages of development. J Anim Sci 2003, 81(11):2826-2839. 
51. Nakayama N, Han CE, Scully S, Nishinakamura R, He C, Zeni L, Yamane H, Chang D, Yu D, Yokota T, et al: A novel chordin-like protein inhibitor for bone morphogenetic proteins expressed preferentially in mesenchymal cell lineages. Dev Biol 2001, 232(2):372-387.

52. Burns KH, Owens GE, Fernandez JM, Nilson JH, Matzuk MM: Characterization of integrin expression in the mouse ovary. Biol Reprod 2002, 67(3):743-751.

53. Campbell ID, Humphries MJ: Integrin structure, activation, and interactions. Cold Spring Harb Perspect Biol 2011, 3(3).

54. Cook-Mills JM, Marchese ME, Abdala-Valencia H: Vascular cell adhesion molecule-1 expression and signaling during disease: regulation by reactive oxygen species and antioxidants. Antioxid Redox Signal 2011, 15(6):1607-1638.

55. Russell DL, Doyle KM, Ochsner SA, Sandy JD, Richards JS: Processing and localization of ADAMTS-1 and proteolytic cleavage of versican during cumulus matrix expansion and ovulation. J Biol Chem 2003, 278(43):42330-42339.

56. Boerboom D, Russell DL, Richards JS, Sirois J: Regulation of transcripts encoding ADAMTS-1 (a disintegrin and metalloproteinase with thrombospondin-like motifs-1) and progesterone receptor by human chorionic gonadotropin in equine preovulatory follicles. J Mol Endocrino 2003, 31(3):473-485.

57. Yung Y, Maman E, Konopnicki S, Cohen B, Brengauz M, Lojkin I, Dal Canto M, Fadini R, Dor J, Hourvitz A: ADAMTS-1: a new human ovulatory gene and a cumulus marker for fertilization capacity. Mol Cell Endocrinol 2010, 328(1-2):104-108.

58. Sriraman V, Eichenlaub-Ritter U, Bartsch JW, Rittger A, Mulders SM, Richards JS: Regulated expression of ADAM8 (a disintegrin and metalloprotease domain 8 ) in the mouse ovary: evidence for a regulatory role of luteinizing hormone, progesterone receptor, and epidermal growth factor-like growth factors. Biol Reprod 2008, 78(6):1038-1048.

59. Klein T, Bischoff R: Active metalloproteases of the A Disintegrin and Metalloprotease (ADAM) family: biological function and structure. J Proteome Res 2011, 10(1):17-33.

60. Smith GW, Juengel JL, McLntush EW, Youngquist RS, Garverick HA, Smith MF: Ontogenies of messenger RNA encoding tissue inhibitor of metalloproteinases 1 and 2 within bovine periovulatory follicles and luteal tissue. Domest Anim Endocrinol 1996, 13(2):151-160.

61. Sessions DR, Vick MM, Fitzgerald BP: Characterization of matrix metalloproteinase-2 and matrix metalloproteinase- 9 and their inhibitors in equine granulosa cells in vivo and in vitro. J Anim Sci 2009, 87(12):3955-3966.

62. Hasegawa A, Kumamoto K, Mochida N, Komori S, Koyama K: Gene expression profile during ovarian folliculogenesis. J Reprod Immunol 2009, 83(1-2):40-44

63. John GB, Shidler MJ, Besmer P, Castrillon DH: Kit signaling via PI3K promotes ovarian follicle maturation but is dispensable for primordial follicle activation. Dev Biol 2009, 331(2):292-299.

64. Fortune JE, Yang MY, Muruvi W: In vitro and in vivo regulation of follicular formation and activation in cattle. Reprod Fertil Dev 2011, 23(1):15-22.

65. Kobayashi S, Kohda T, Miyoshi N, Kuroiwa Y, Aisaka K, Tsutsumi O, Kaneko-Ishino T, Ishino F: Human PEG1/MEST, an imprinted gene on chromosome 7. Hum Mol Genet 1997, 6(5):781-786.

66. Assou S, Anahory T, Pantesco V, Le Carrour T, Pellestor F, Klein B, Reyftmann L, Dechaud H, De Vos J, Hamamah S: The human cumulus-oocyte complex gene-expression profile. Hum Reprod 2006, 21(7):1705-1719.

67. Forbes AJ, Lin H, Ingham PW, Spradling AC: Hedgehog is required for the proliferation and specification of ovarian somatic cells prior to egg chamber formation in Drosophila. Development 1996, 122(4):1125-1135.

68. Aad PY, Echternkamp SE, Sypherd DD, Schreiber NB, Spicer L: The hedgehog system in ovarian follicles of cattle selected for twin ovulations and births: evidence of a link between the IGF and hedgehog systems. Biol Reprod 2012, 87(4):79.

69. Ohlig S, Pickhinke U, Sirko S, Bandari S, Hoffmann D, Dreier R, Farshi P, Gotz M, Grobe K: An emerging role of Sonic hedgehog shedding as a modulator of heparan sulfate interactions. J Biol Chem 2012, 287(52):43708-43719.

70. Watson LN, Mottershead DG, Dunning KR, Robker RL, Gilchrist RB, Russell $\mathrm{DL}$ : Heparan sulfate proteoglycans regulate responses to oocyte paracrine signals in ovarian follicle morphogenesis. Endocrinology 2012, 153(9):4544-4555.
71. Lee AH, Iwakoshi NN, Glimcher LH: XBP-1 regulates a subset of endoplasmic reticulum resident chaperone genes in the unfolded protein response. Mol Cell Biol 2003, 23(21):7448-7459.

72. Nakamura T, Lipton SA: Cell death: protein misfolding and neurodegenerative diseases. Apoptosis 2009, 14(4):455-468.

73. Jacobson NG, Szabo SJ, Weber-Nordt RM, Zhong Z, Schreiber RD, Darnell JE $\mathrm{Jr}$, Murphy KM: Interleukin 12 signaling in T helper type 1 (Th1) cells involves tyrosine phosphorylation of signal transducer and activator of transcription (Stat)3 and Stat4. J Exp Med 1995, 181(5):1755-1762.

74. Bacon CM, Petricoin EF 3rd, Ortaldo JR, Rees RC, Larner AC, Johnston JA, O'Shea JJ: Interleukin 12 induces tyrosine phosphorylation and activation of STAT4 in human lymphocytes. Proc Natl Acad Sci U S A 1995, 92(16):7307-7311.

75. Love DC, Krause MW, Hanover JA: O-GlcNAc cycling: emerging roles in development and epigenetics. Semin Cell Dev Biol 2010, 21(6):646-654.

76. Sutton-McDowall ML, Mitchell M, Cetica P, Dalvit G, Pantaleon M, Lane M, Gilchrist RB, Thompson JG: Glucosamine supplementation during in vitro maturation inhibits subsequent embryo development: possible role of the hexosamine pathway as a regulator of developmental competence. Biol Reprod 2006, 74(5):881-888.

77. Sutton-McDowall ML, Gilchrist RB, Thompson JG: The pivotal role of glucose metabolism in determining oocyte developmental competence. Reproduction 2010, 139(4):685-695.

78. Irving-Rodgers HF, Catanzariti KD, Aspden WJ, D'Occhio MJ, Rodgers RJ: Remodeling of extracellular matrix at ovulation of the bovine ovarian follicle. Molec Reprod Devel 2006, 1292:1302.

79. Irving-Rodgers HF, Rodgers RJ: Ultrastructure of the basal lamina of bovine ovarian follicles and its relationship to the membrana granulosa. J Reprod Fertil 2000, 118(2):221-228.

80. Irving-Rodgers HF, Morris S, Collett RA, Peura TT, Davy M, Thompson JG, Mason HD, Rodgers RJ: Phenotypes of the ovarian follicular basal lamina predict developmental competence of oocytes. Hum Reprod 2009, 24(4):936-944

81. Prodoehl M, Irving-Rodgers HF, Bonner WM, Sullivan TM, Micke GC, Gibson MA, Perry VE, Rodgers RJ: Fibrillins and latent TGFbeta binding proteins in bovine ovaries of offspring following high or low protein diets during pregnancy of dams. Mol Cell Endocrinol 2009, 307(1-2):133-141.

82. Hatzirodos N, Hummitzsch K, Irving-Rodgers HF, Harland ML, Morris SE, Rodgers RJ: Transcriptome profiling of granulosa cells from bovine ovarian follicles during atresia. BMC Genomics 2014. in press.

83. Irizarry RA, Hobbs B, Collin F, Beazer-Barclay YD, Antonellis KJ, Scherf U, Speed TP: Exploration, normalization, and summaries of high density oligonucleotide array probe level data. Biostatistics 2003, 4(2):249-264.

84. Hotelling $\mathrm{H}$ : Analysis of a complex of statistical variables into principal components. J Educ Psychol 1933, 24:417-441, 498-520.

85. Eisenhart $C$ : The assumptions underlying the analysis of variance. Biometrics 1947, 3(1):1-21.

86. Ashburner M, Ball CA, Blake JA, Botstein D, Butler H, Cherry JM, Davis AP Dolinski K, Dwight SS, Eppig JT, et al: Gene ontology: tool for the unification of biology. The Gene Ontology Consortium. Nat Genet 2000, 25(1):25-29

87. Zheng Q, Wang XJ: GOEAST: a web-based software toolkit for gene ontology enrichment analysis. Nucleic Acids Res 2008, 36(Web Server issue): W358-W363.

doi:10.1186/1471-2164-15-24

Cite this article as: Hatzirodos et al:: Transcriptome profiling of granulosa cells of bovine ovarian follicles during growth from small to large antral sizes. BMC Genomics 2014 15:24. 